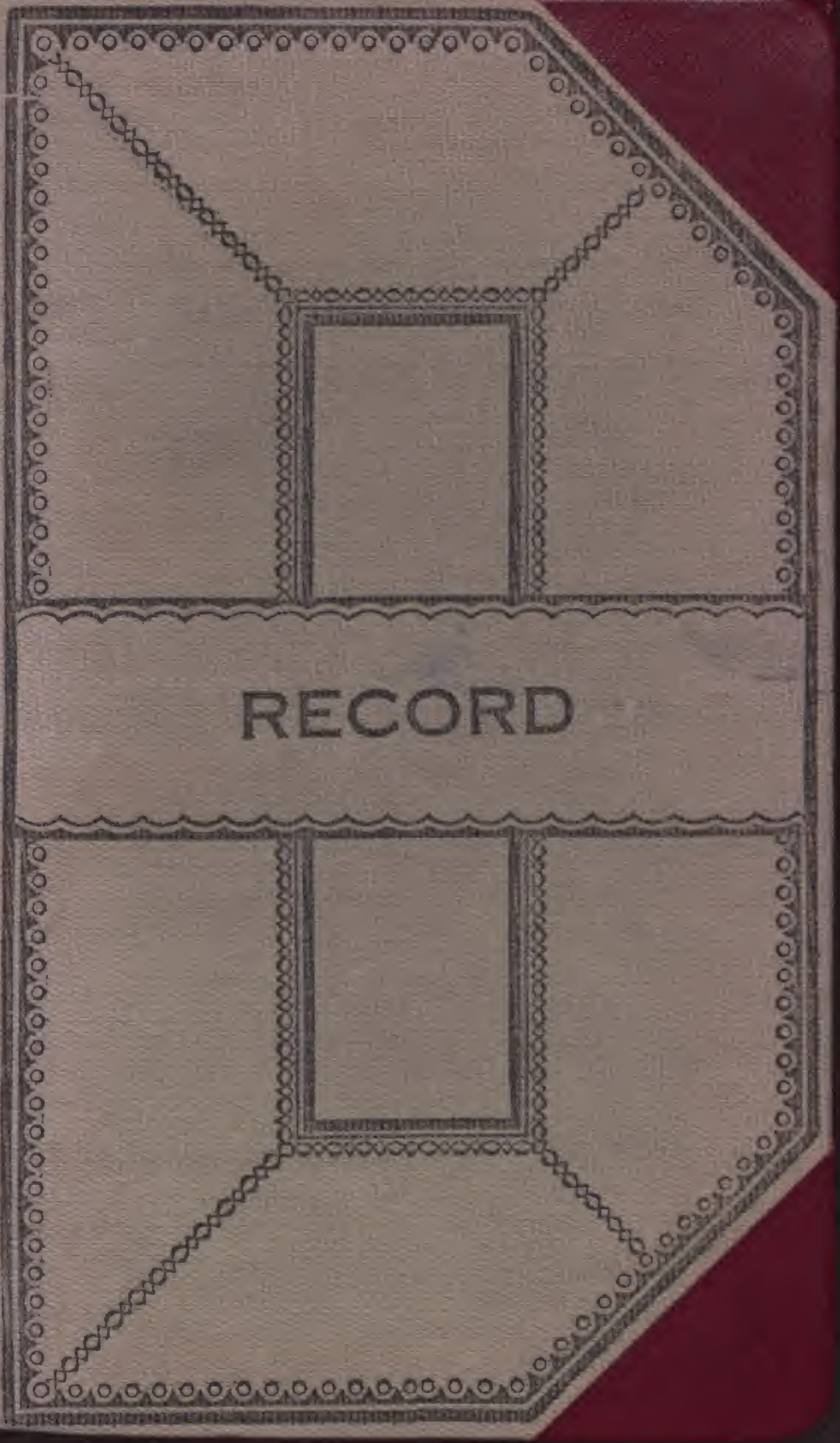



Colicetian and Meld Hote Brok

$$
\text { No. } 42
$$

(Jan. 29, 1956 - Fat. 24, 1956)

$$
\text { (36627 -.. 36738) }
$$

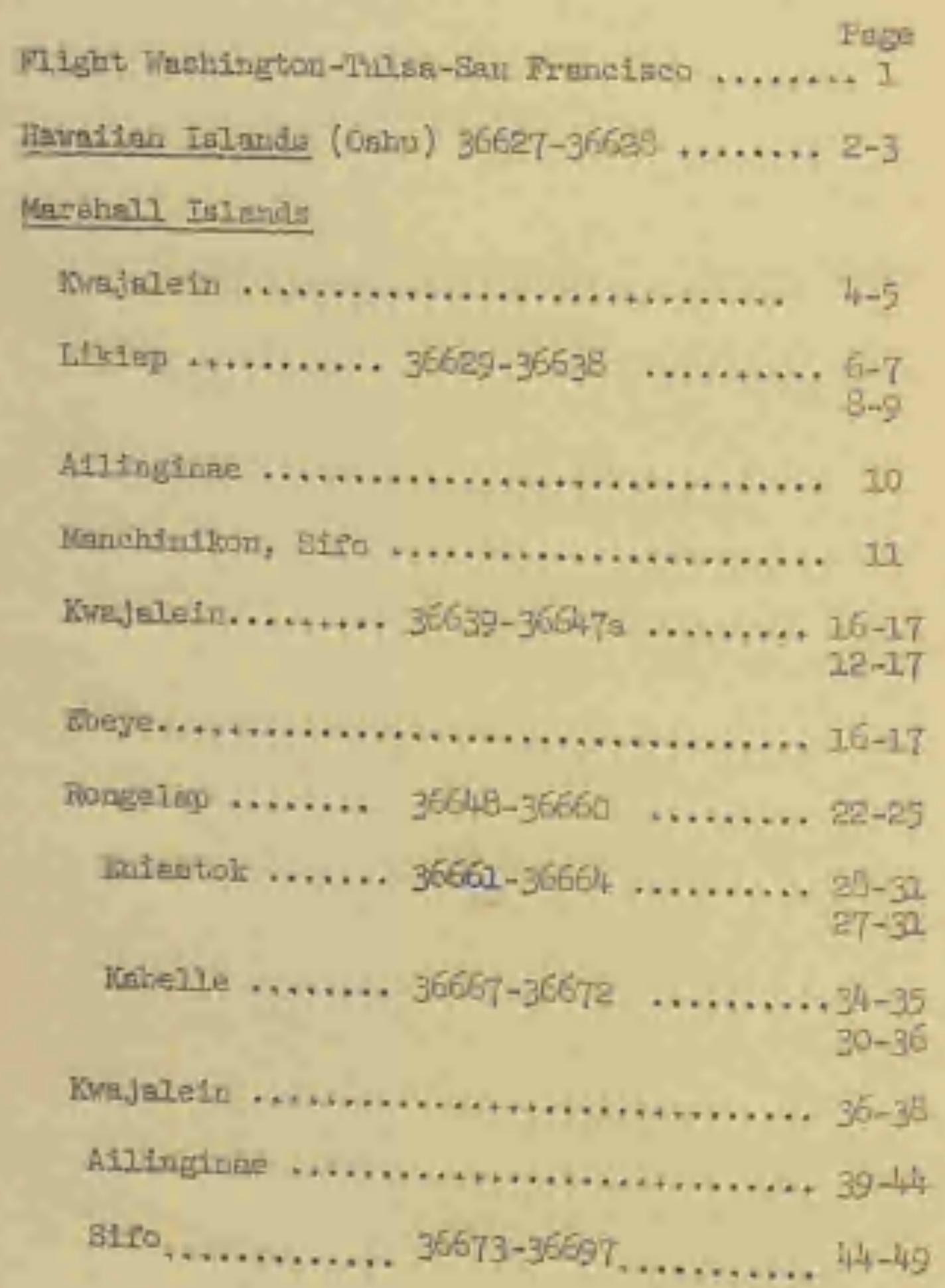

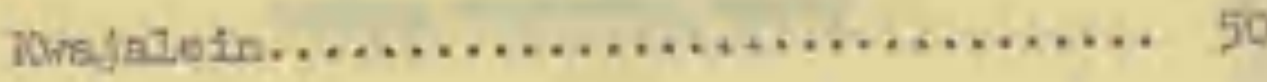

Rouger1h

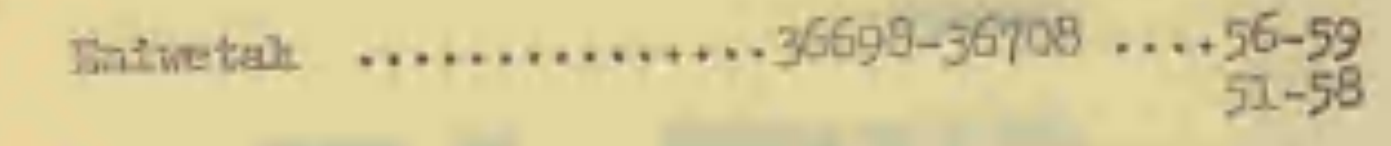

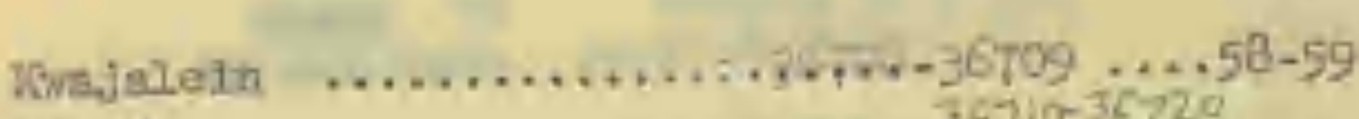

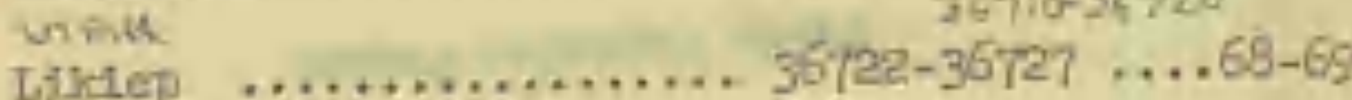

Rongotitg

Gegen $\ldots \ldots \ldots \ldots \ldots \ldots \ldots .36728-36737 \ldots \ldots 74-75$

$$
\text { 1 } 70-76
$$

hnimato....................... 7647

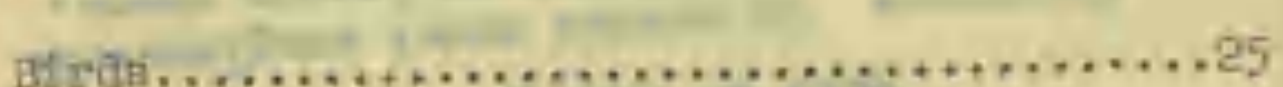

Insects $\ldots \ldots \ldots \ldots \ldots \ldots \ldots+\ldots \ldots \ldots \ldots \ldots, 7_{6}$

Ilanutian Iglanda (Oahu) ..,.36738

$80-81$

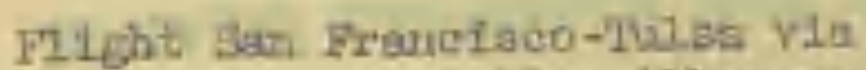
Sun Jonqudu Valley, Albuquorqne, Amar 1715 , ete. ................... Be -83 


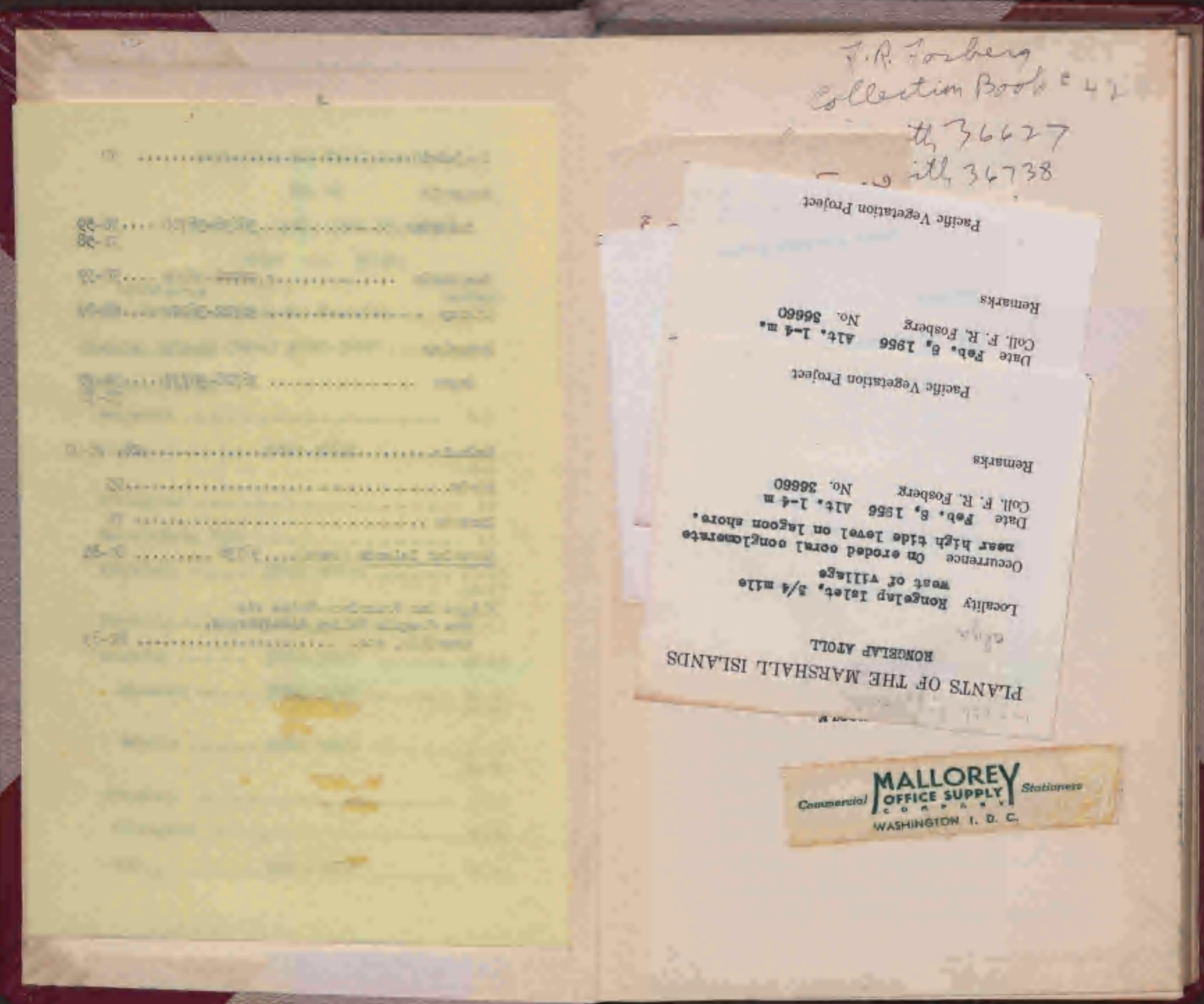


PLANTS OF THE MARSHALL ISLANDS RONGELAP ATOLL

Locality Rongelap Islet, $3 / 4$ mile west of village

Occurrence On eroded ooral oonglamerate near high tide level on lagoon shore.

Date Feb. 8, 1956 Alt. 1-4 m

Coll. F. R. Fosberg No. 36660

Remarks

Pacific Vegetation Project
PLANTS OF THE MARSHALL ISLANDS RONGELAP ATOLL

Celymperes

Locality Gogen Islet

Occurrence Cormon on branohes of trees

Date Feb. 15, 1956 Alt, 1-4 m

Coll, F. R. Fosberg No. 36753

Remarks

Pacific Vegetation Project

\section{PLANTS OF THE MARSHALL ISLANDS} RONGELAP ATOLL

Calymperes

Locality Gegen Islet

Occurrence Common on branches of trees

Date Feb. 15, 1956 Alt, 1-4 m

Coll. F. R, Fosberg No. 36733

Remarks

Pacific Vegetation Project

\section{PLANTS OF THE MARSHALL ISLANDS} RORGBLAP ATOLL

\section{Calymperes}

\section{Locality Gegen Islet}

Occurrence Cocmon on branghes of trees

Date Fob. 15, 1956 Alt. 1-4 m

Coll. F. R. Fosberg No. 36783

Remarks 


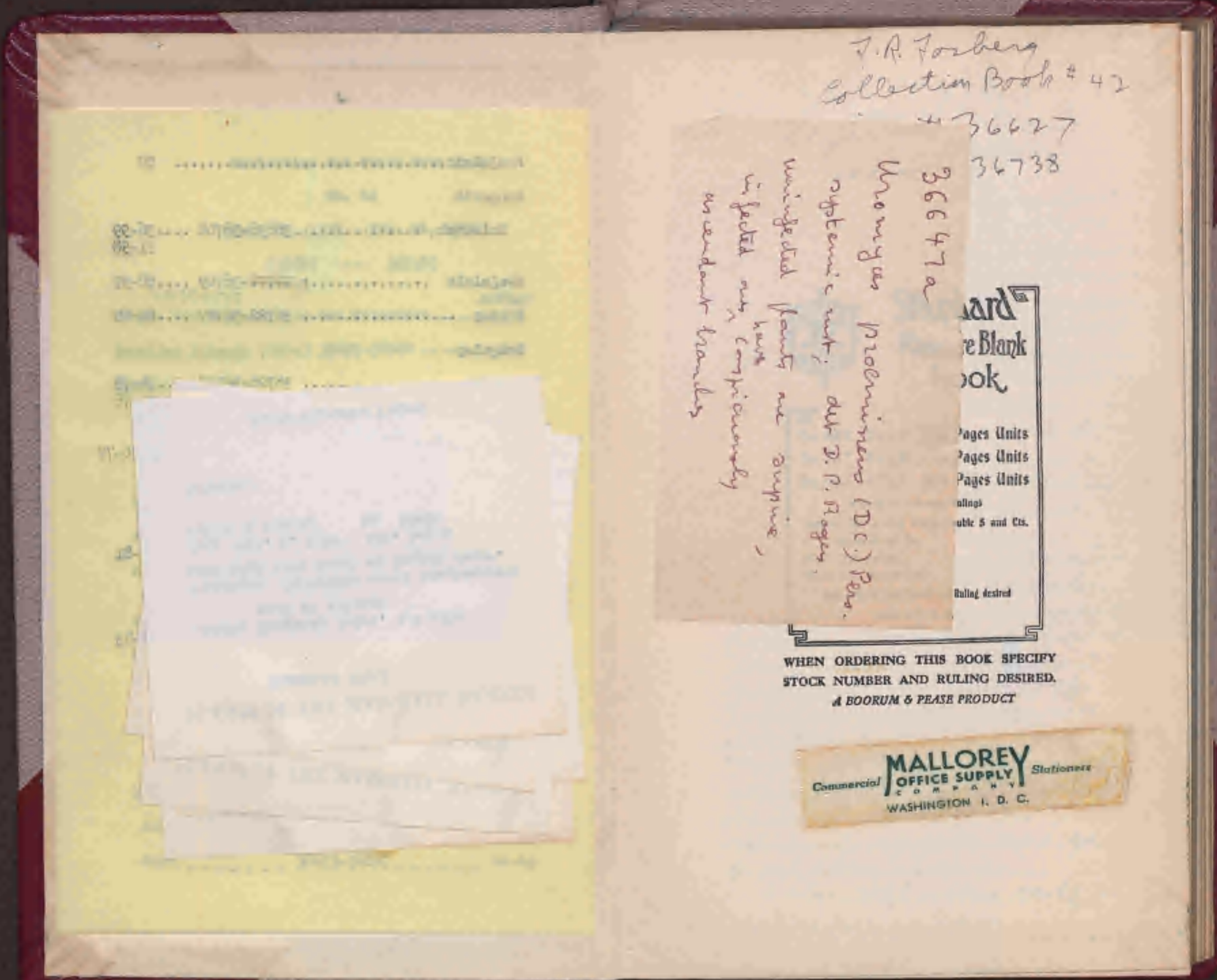




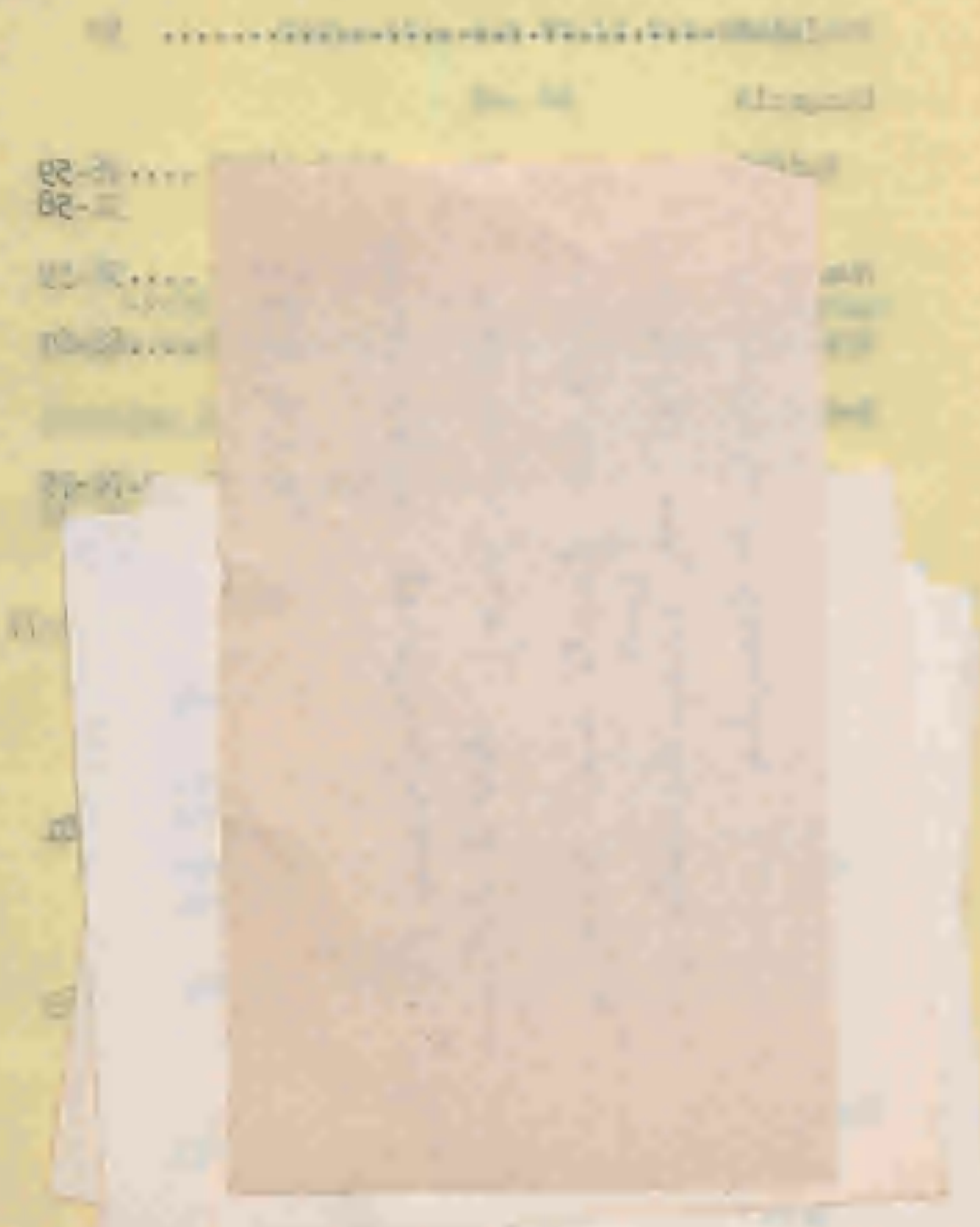

$$
\begin{aligned}
& \text { T. P. Foritheng } \\
& \text { onelectim Borb it } 42 \\
& \text { Pregin with } 36427 \\
& \text { and with } 36738
\end{aligned}
$$

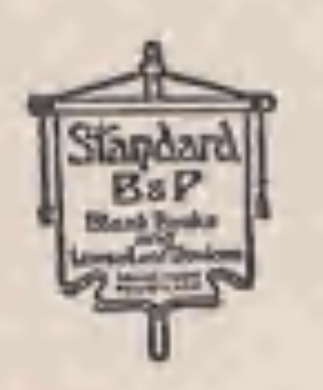

\begin{tabular}{|c|}
\hline Do. $665991 / 2 \times 6 \quad 120$ Pagss Units \\
\hline Do. $66791 / 2 \times 6 \quad 200$ Pages Units \\
\hline Do. $66891 / 2 \times 6 \quad 300$ Pages Units \\
\hline Meste la the Tollowing Rulinust \\
\hline 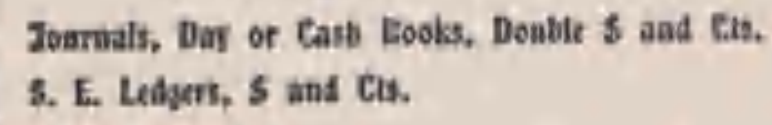 \\
\hline Double Entry Leatpers \\
\hline Reciorat wite Margin Uint \\
\hline When ordefine Elve Number and Ralling dessirnd \\
\hline Made in U. S. A. \\
\hline
\end{tabular}

\section{STändard Miniature Blank Book}

WHEN ORDERING THIS BOOK SPBCIFY STOCE NUMBER AND RULING DESIRED. $\triangle$ BOORUM G PEASE PRODUCT

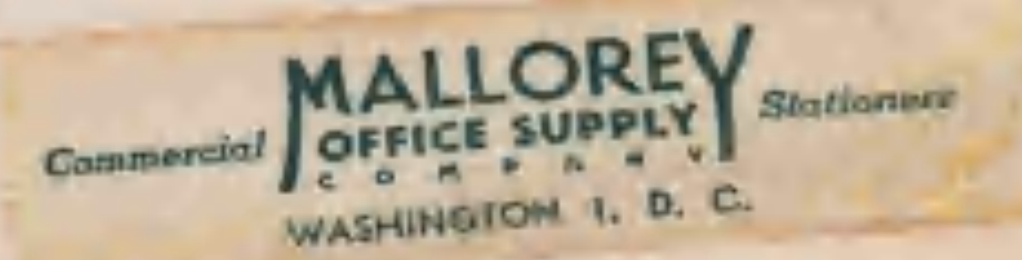




$$
\begin{aligned}
& \text { F.R Tophen } \\
& \text { selection Boro: } 42 \\
& \text { fiogen with } 36627 \\
& \text { end with } 36738
\end{aligned}
$$

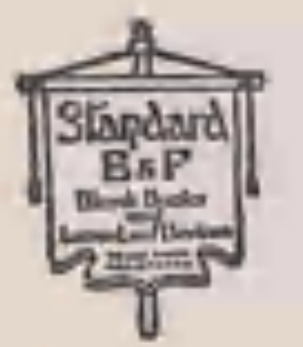

SFändard Miniature Blank Book,

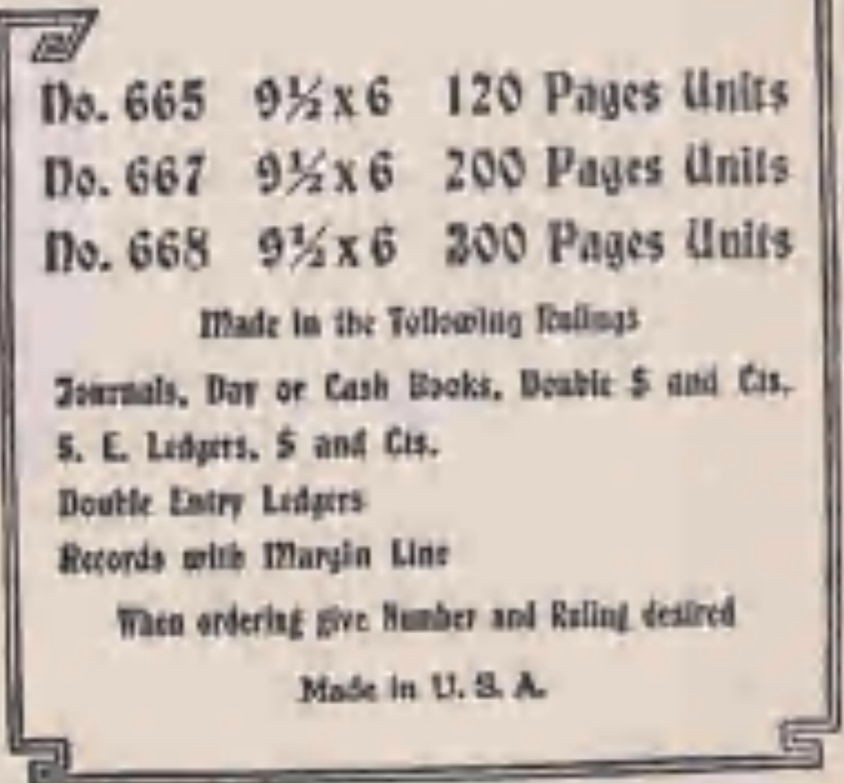

WHRN OKDERING THIS BOOK SPECIFY STOCK NUMBRR AND RULING DESIRED. A BOORUM E PEASI PRODUCT

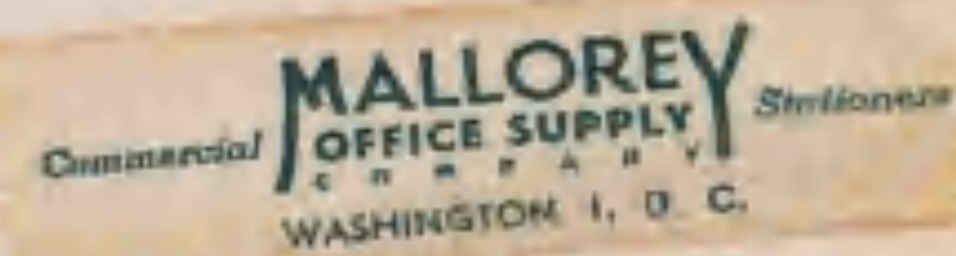




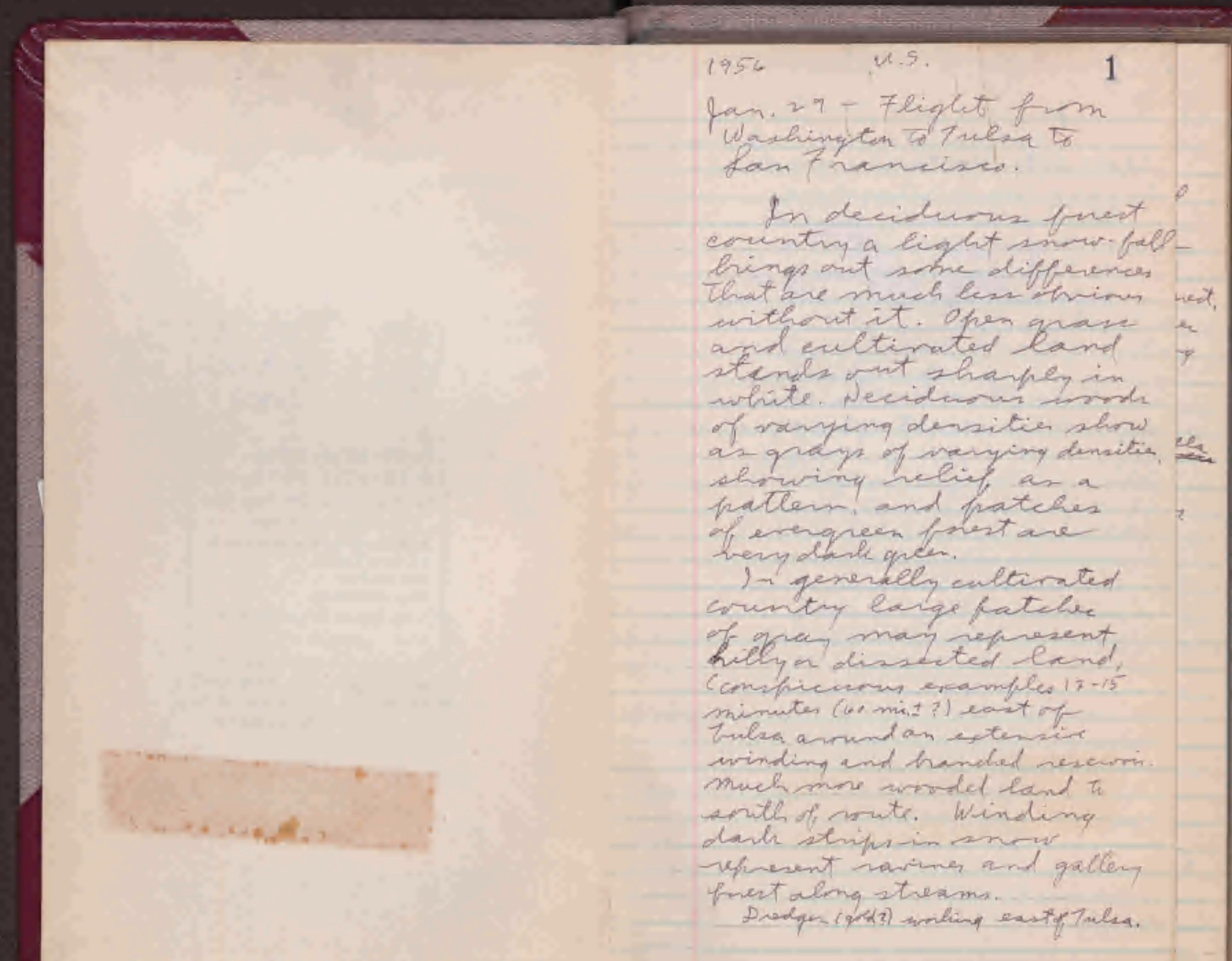




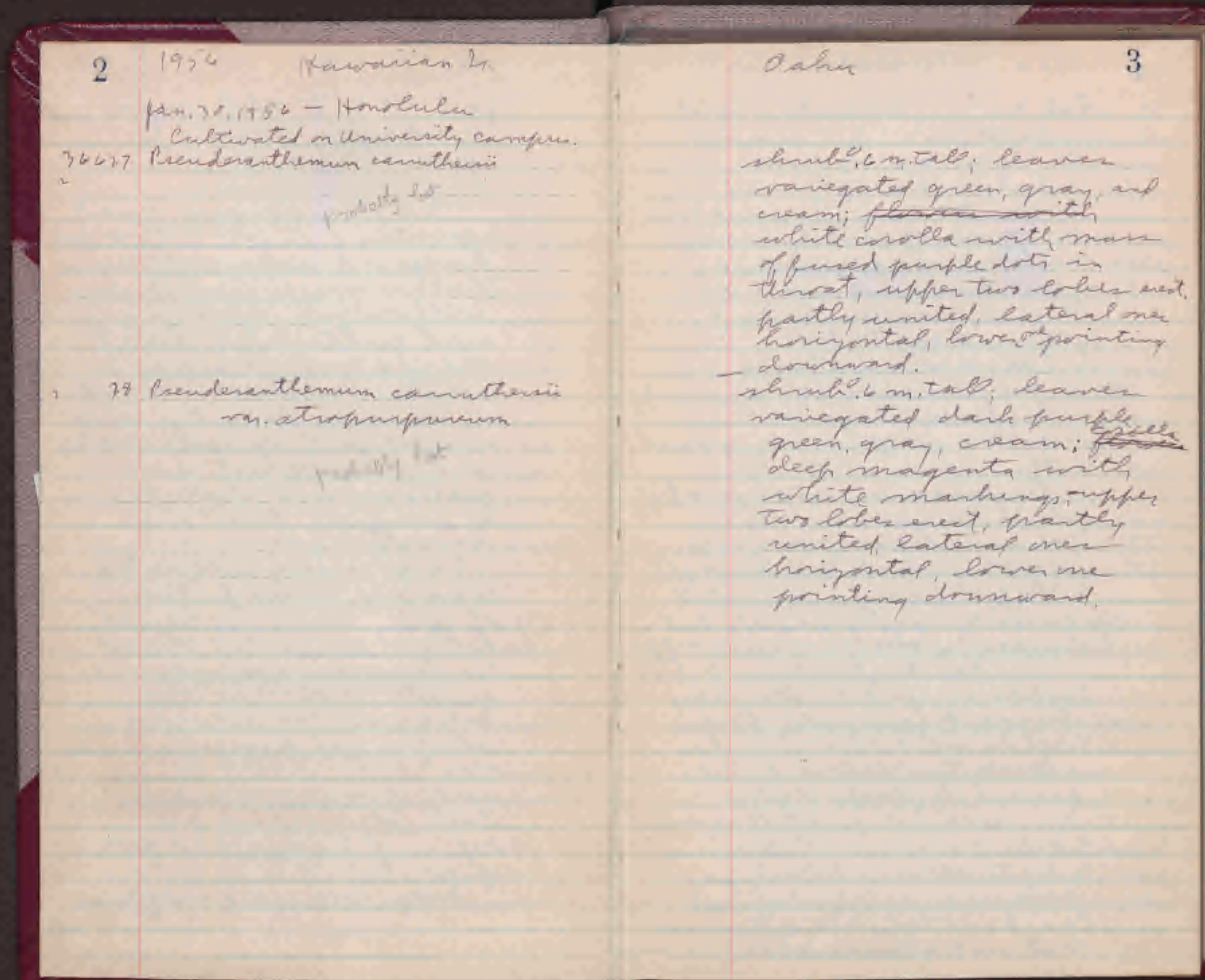




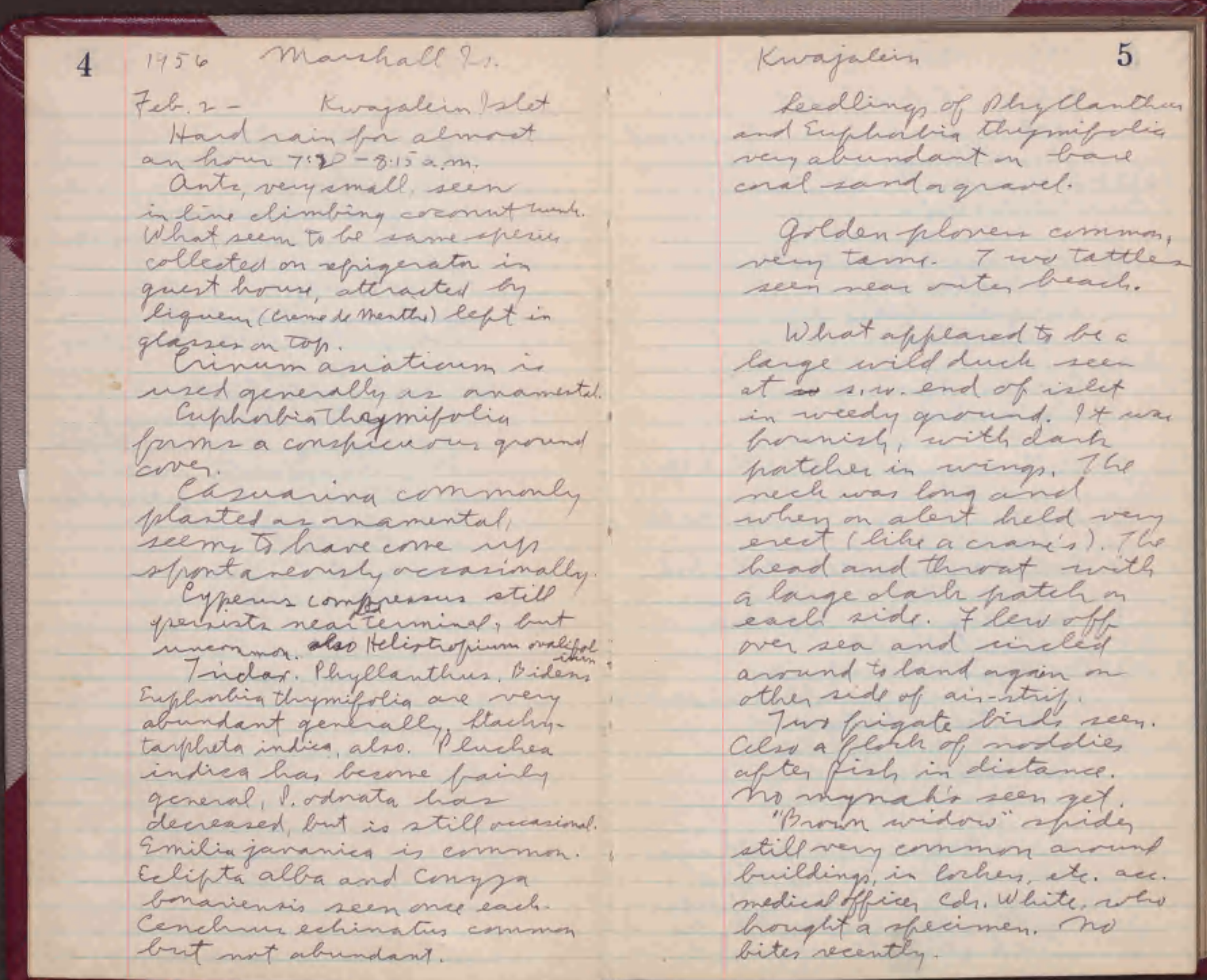


61956 marshall9.

7eb. 4 - Ribief I set

In gardens and armed lwellengs in villap.

36629 Borrainut

330 Casuarina equiretifolir $L$.

* planted

1 31 Bongainvicled glaba ching

$v_{2} \quad 32$ Cipcas circinalis.

I 33 artrearpus altilis (Pouls.) Frab.

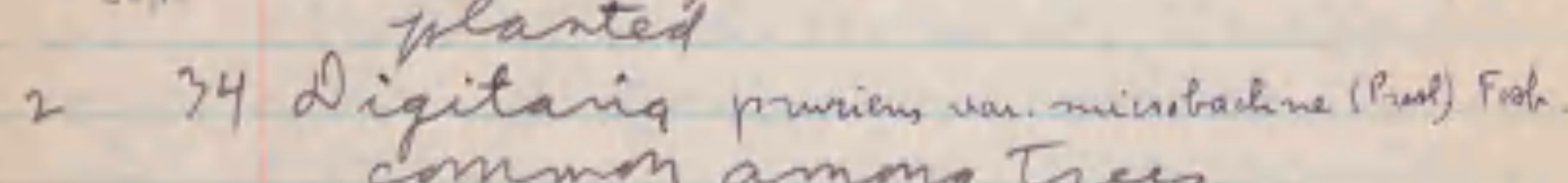

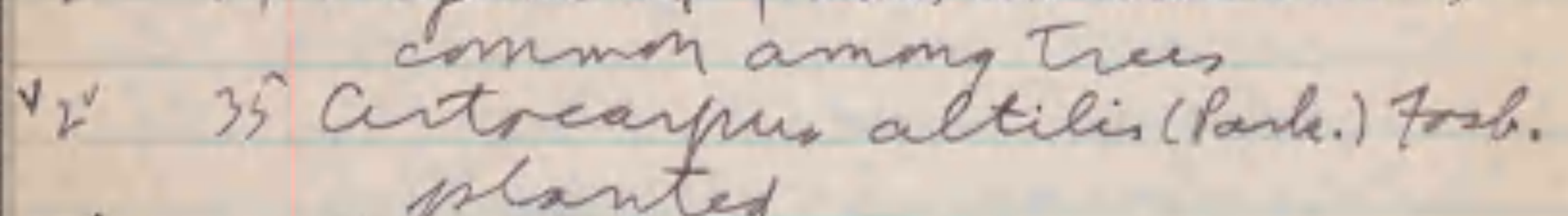

$3^{v} 36$ Penciented glanca (L.) Benth

1 planted?

'37 Acalynh amentacen

vas. Wilkesiang $(M,-A$.$) Fold$. planted as helge $\checkmark 38$ Delmix requa (rojigh Raf.

Bananas anl pafiayas commey pleanted, the veithey eshecialling preey. neithen esheciallychentic.
Likief atoll

7

scandent shub with axillery spines; bact dull irange-red.

the abrutf $8 \mathrm{~m}$. Tall said to hare been with rallary spines, ract. cirmon majent.

thee im. tall; sail to have been hinght fim anno.

-3tres seen. "lauit said to be seedy.

largetree; fwit said

- tr b́ seedy.

teargecump of

shrubh, ztemi 4 m.tall. reddish but wern

chlartic.

ved tree 5 mitall, widespreading, zterile, olmast leafless.

tree seem in ferwes. 1 wo pitchantia pacifica tres, quite tall $(5 \mathrm{~m})$, in ferwa. clump of Rurselia much

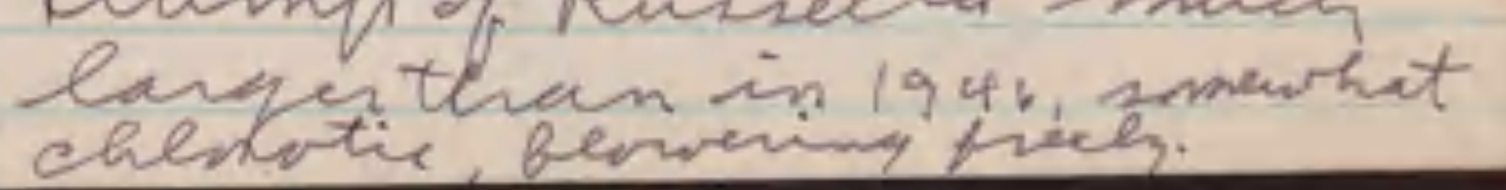


8

1956 marstall?

Rtachytaphet.

still quaring and pleverin

ineadpuit, naid to be of abnat 6 varieties fome are in fruit nar, a ver few puit al most iipe. Thb learez are badey infested ly mealy buys. a prabe vennillin Hifpeastium and evinum yeylamicum quanim

of weeds - Phyllanthm anm ir veryemm exm everpurhere in wateant ent and side of path. eveally very emmm and - heterthylla fairly ammon cleasimal is uraste spats. Sleusine indica sery crmmm qenerall, in waste phets.

Gowotar Cymalm als very enmmon levally fontming a thin sont. vaqurstis ammbilis is als very onmm.
Liluef atol.

One of the sisters ha fim 4 molewh and verated them. chereare mang (dead) Fiqal montain apple Lurimam chern quara.

they are oney a protar $=0$ tall as pet, and ter watera foo them is mot gat.

vibublaw had a year and a hulf excefitfor a invarte of din shell of 2 mante. Waterciscerns a ve ew and theyare having $t$ use wele wate fro lawndry. $t$ he sister. de mathinow abrit. any of th well becming dinzeasm. 


\section{6 manshall is}

Notes taken fom aerial photas ir Photolab m

Ailinginae obliques $9-12-55$ knax 9. densely wrodad. \& let, from Bohonguren with extensivel, developed evosion rampe on seausand side, a little sand on larewsich.

iste wi. B Boknyumen is a eng stip of peatform and ension samp with ating letacled sand islet trwand lagoon. Kuibuen?. easteur pation warded excepty far s.e. annen, fureonqation Trest has been striffes clean much as in vetinila with a wiw of mall duner and busher alony logesn share. Ribinani? - wroded. prosibly a rery few cremuth.

Enivetakhe 9. (1) scattered trees on quany whond. (Penhap is actwally isex east of (nimetakku)

Enibuh 9. - largely heanted to cranntes Moginis. wroded. dicingines

Manchuman? - resded. Lifo $)-(12-9-55)$ densely
unoded, larqe tiees

sem th be Piemia shew a soft fine texctere bat comuts, (tahen at 800 ' n. wo end of ?.) 
12

1956 manthaep 2 .

700.5 - humseng in old

terminal.

Plants quaring in quantit, in perts and frames.

some shelted, sme notionsty

(t)

Kibiscas (amameatal hyphid Cossia alata

Lolandia sh.

Acalypha amintaces w. witherime Crdiceum raviegatum

Pisonia ontendis

Polpacias sewtellarin

Gandenia jasminorides

Pilzacia grilfyeer

Euphnbia pulchenima

neviumsp.

alovasiasp.

Acindapins anem

peuderant hemum cam therii

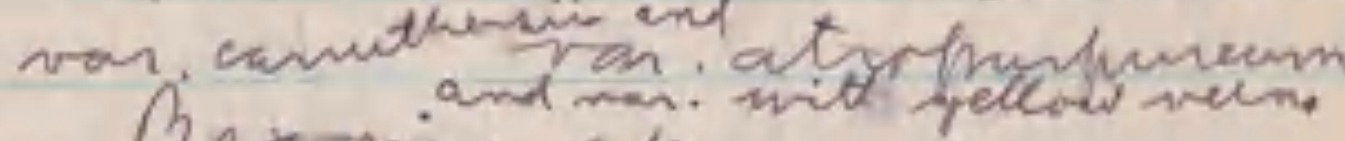

Beganin in.

At Ltrelitzia reginas

Condylime temminalis

Polykidium sererpendra

allamanda cathatien ran.

tibiscus mutabilis

Poeyseias tricrchleata

Pentas laneerlat.

Vanch Aatis foochins

Gomphena of rova

Angelmia (biatpuple menst.

Jinnia legams

Caniax papaya
Nurajabin

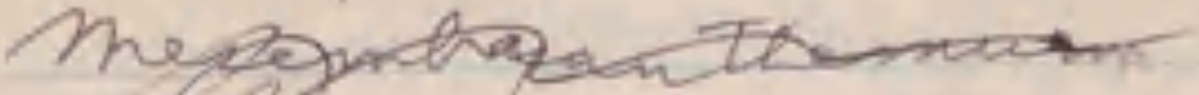

st

Lesumium patulaesatimm

Hedychiom conmeniun

Lredmum ligerpendion

Canna indiag

Massaia actimphula

Thespesia populnex

minalilis ialapa

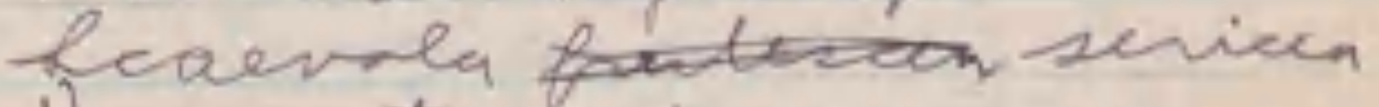

Dunanta repene

Cocelenba unifrena

termandia semena

Ravenala malpascariemir

Baringtria asiatica

Musa sapientum

7 aber naemontang conmavis elengate Dravaem-lhe mift andyline-liksplant with small lancerlate lus.

Clpinia puppurata aleunita moluceana?

Brugaimniller spectabili

Pieffembachia maculata Pritchandia Mp.

Galadimm bivar

phrevis th

Cascuaring efunsetifrlia

Ananas comosur

Ashlenimm midus

cibrtium s.

hephnolepin $x_{\text {. }}$

amit (Phajies?

Lasminum pubercen. 
Phyllanthus nimsens Delmix reqia Catharanth

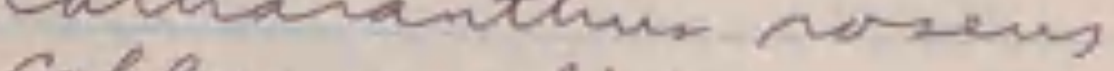
erfper arabica Cinnm asiatioum? Rhoes diveren spativers artreapus altis Plumeria whera

Plumein sp.

Cores mucipen

arecrid fuem?

2 mident. shrubs Anthurium cammon red) and me with eanqe

sualeped ens. Pavleria cintata (wite) pemphis aciduen Hemir aqhis repens Mninda citrifolia quettanda specinas Erythrima indiea? Pandanus tectrims Lansevicia (brad mottled) Bryophylem pinnatum inphntia hetarnhylla Lifizcus achuretalus Viter trifolia fohimm tere inthiplinas Elens sentellaria Polyscias funticrsa bolysian sp. (commpled) Ruellia longifolia Tabebria pentaphylla
Pedilathes tithmmacoids fibisens tiliasenr

clenodendrum inerme

muraya inamiculata Asparagur sferengeri
sic Canavalta sp.?

therdia perumiam Euphovis llange, spatolate

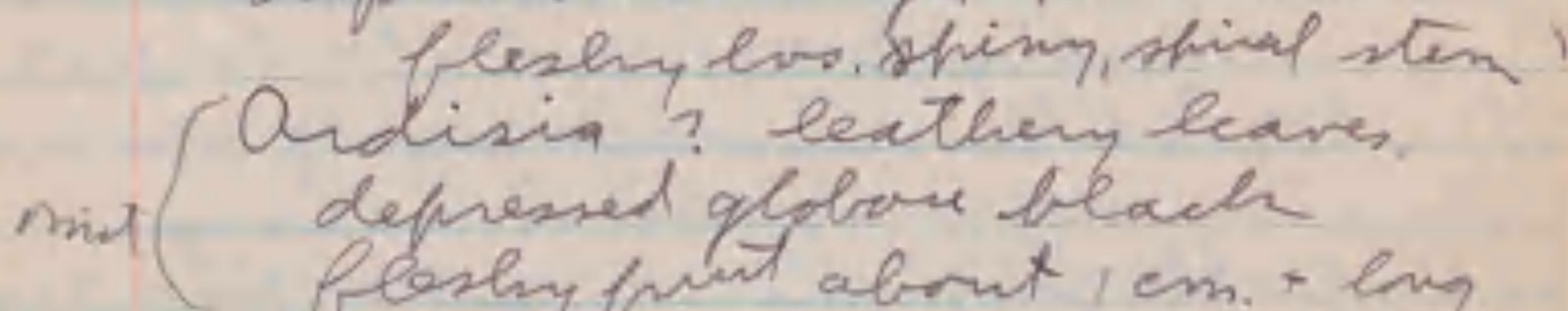
floshy punt about $1 \mathrm{em}$. I lng. deystasin qangetica "for ple al montor Cuphtrateqia parifere midi Kigctia on Apathoded snerremia tubersea Acalypha hisfida Revinm oleander Russelia equisetifomis

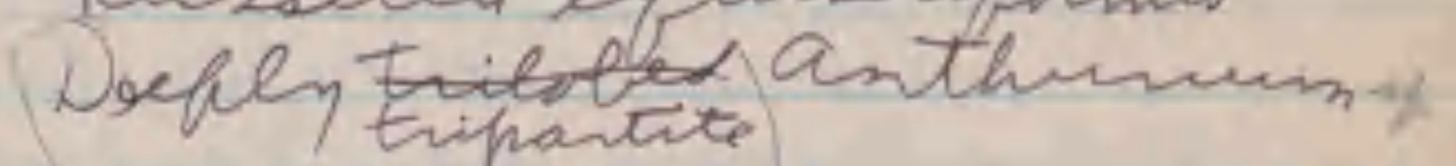
Ostermeles anthyllidif persea amerieam Ghursia oppositifolis? para casei Piles mierphor. Posloearpus inda.?

Cucumis sation (ipl) fhometorev Pliclosendrum oxycandium Macadamia temiforia molenbit? largernhind Equipenmum : 
161954 marshall \&. 7eb.5-kwajalein 2slet, with and yrat sile.

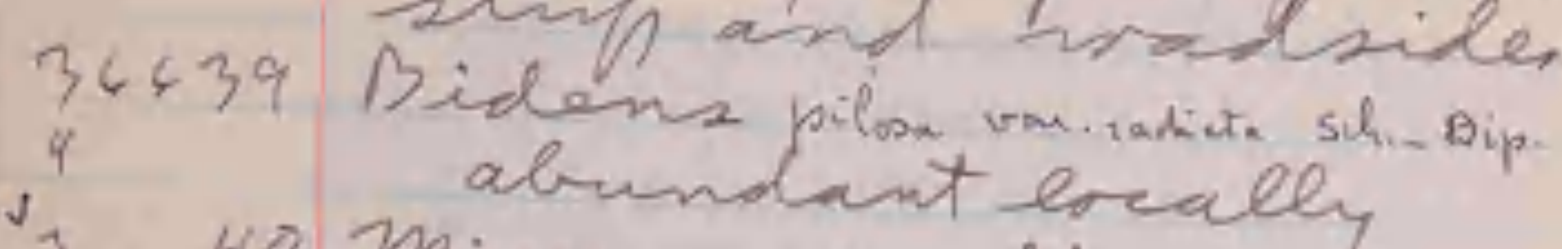

40 Mimsondant locally

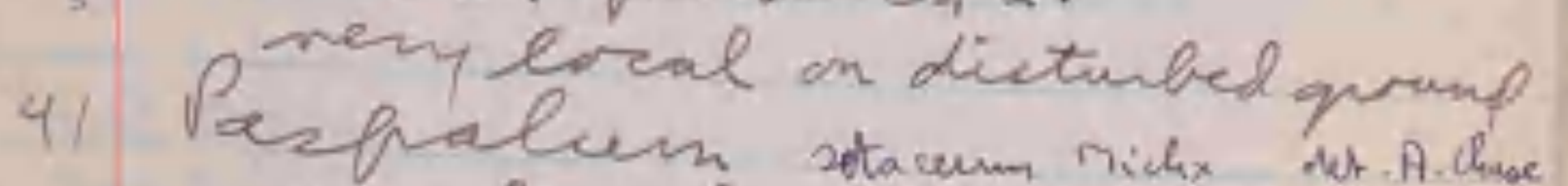

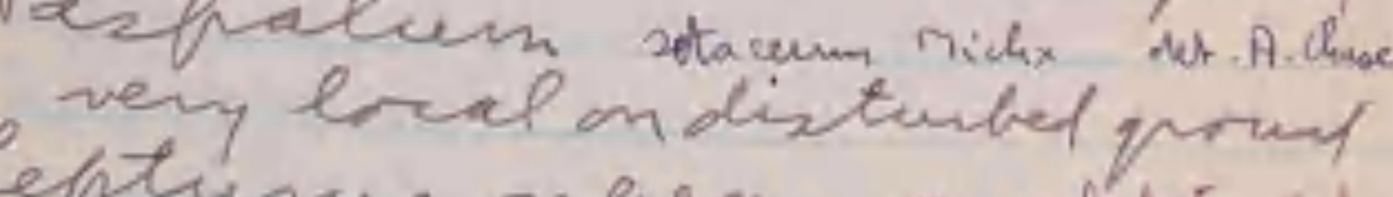

- 3 42 Repturus repens vm oubulatios ins.

${ }_{13} 43$ Phyllanthus arilding hyllanthur amarms schmot thm. vey abundent

3 44 Paspalum fimbiatum H.B.K.

3 45 nommoc commune vally.

$v_{4} \quad 4 \mathrm{c}$ abindant on hare cral sand

${ }_{4} 46$ Comprga canadensi is cremp.

$\checkmark, 47$ iuphndint lealey

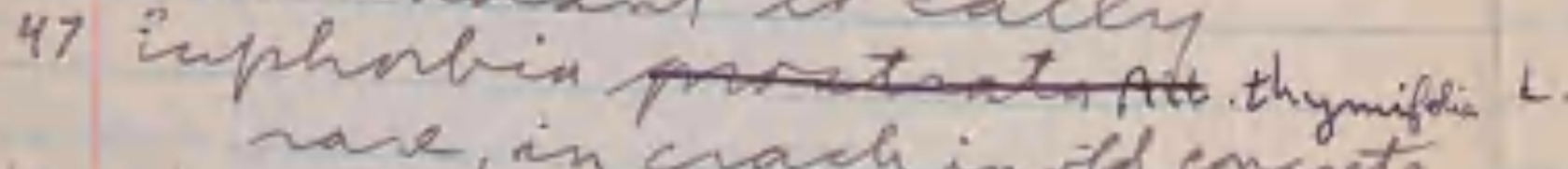

47 Uromyus in crach in old encrete

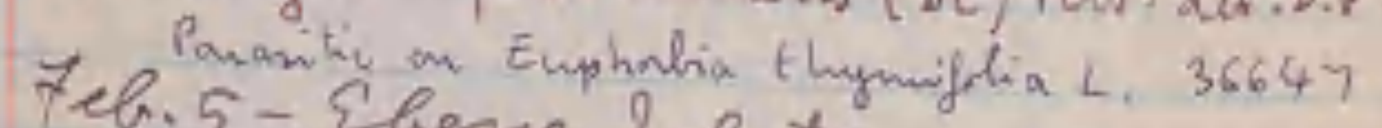
7eb.5 - Ebeye lslet preach on muth and, consider ablepumia, sather pesh poikeng, has ome oshore

Painly iecentey.

haw twi beach naped tans flying on lagrom side of
Krajalein

17

nayp white, disk yellow. leaver sensitive very cherotic; flowers eventes. culms sprealing

spreading

ceaven smewhat gloweres beneath, quener wher eath is filed mp, yedrowi

- on level quind.

culms

- shreading

dachun

evect, flowers white pirplish, prstrate. 
Zas m - 
beach. This is conspic

wowh wind sexlered, and is finged by a of rwith of 7 inmpetta recping dom the weach Whe eat beach is of mand and quarel. Baq 302 is sand from inst above high tidelend. the inasion namp here is verng rough chaving beacha dach on pertot). The npper part iisol much ended berch -

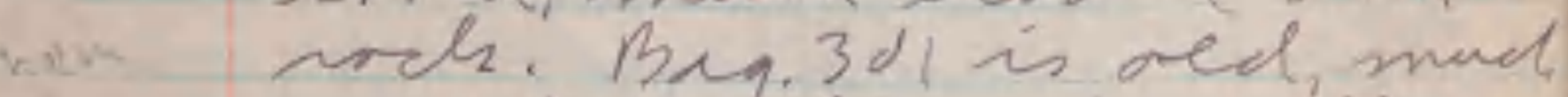
ended bedich which with andonl lays.

on the bech are large inantitis of pumia peboles, the sand, brth on the mpen pouts Jith beach and in the feat well bach of the top of the beads. It is mostey small rrunded fine-graina pebbles, but sme learqu pieces are much ante fush-erreing ( potsibly frm han Benedicto.. fom of it is peain (Bay 3o 5 ) but snme pieces hav small corals quaving bay 303? on them. These shored bea facta inter leng distana disperal 7 ? nqarism.

The "seboi" of ch islet is lined on a prueder crbble vitos, the frument well-nunded. The platfoum protider beneath the in many places and firms a wrugh crosim ramp with considerable ahasion exident.

$$
\text { Onthervindward side }
$$
the Acarenea soub tipen downtiter top of the beach. ontholeewand ride itiere is a flat of covber with with seattrea owsher masthy facora fome Messersehmidis. some quettarda, rmall patcher of unhealtryLorling Reptwos. Back of thi is mised prest of messaschmidia. guettanda and Pismie. alma the beach feaerrea

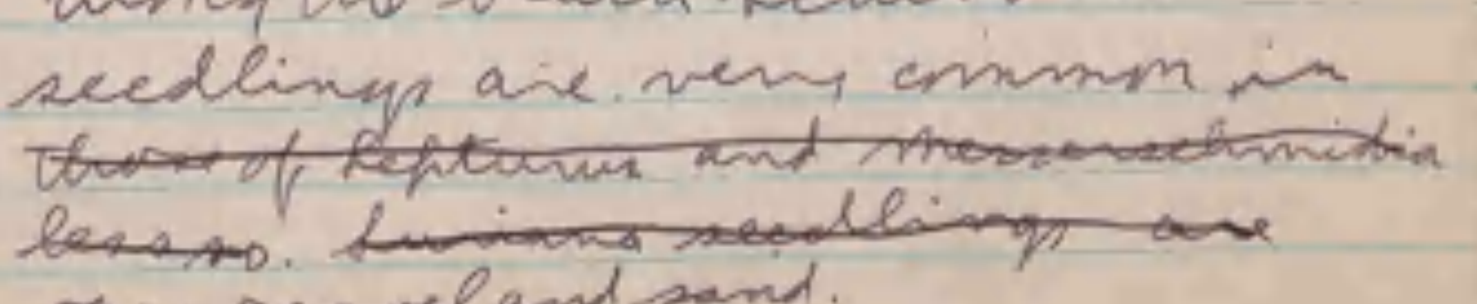
besend. Luend and sand. 
221956 marshall \&s.

7 eb. 7 Renqelap Islet bach fovillage in

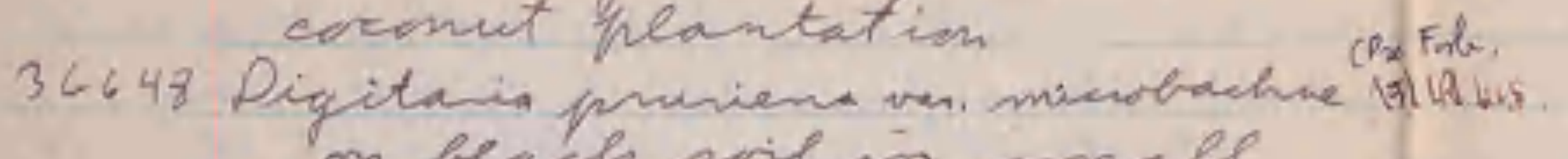
on beach soil in snall

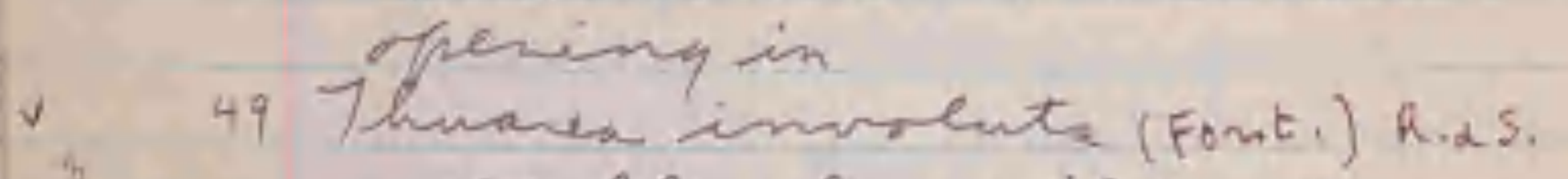
on blach soil, forming gowel cover in

$\checkmark 50$ Pismia qrandis R.B. $\checkmark 51$ guettada speciosa 2.

same - srath side of islet, juct back of beach ridge

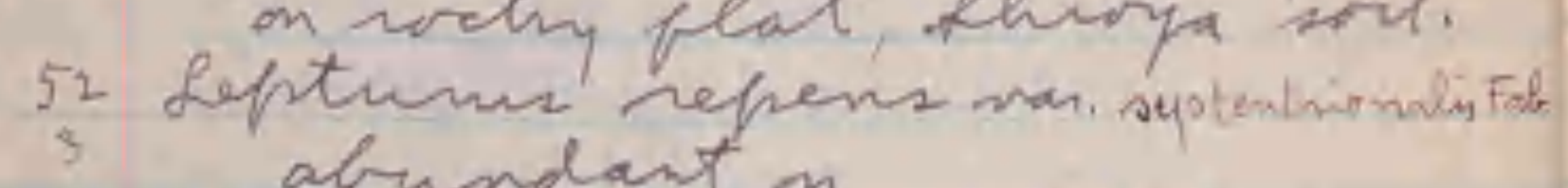
abundant $x$

$\checkmark 53$ Bresharia tetrandra Font. f. local on

rame - coomut plantation arest of nillage.

54 Pandamin testrims crmmon in
Rinqueap atol

23

(voucher for X RDL sample 100)

ereping. (woveler ton XRDL sample 10i)

Tree $15 \mathrm{~m}$. Tall, trumb 25 em, think. (rouche for NRDL sample 102)

true $10 \mathrm{~m}$. tall: flowere whits. paquant, limb of covela (vouches for XRDL sample 103)

tufted. (wowcher for XROL sample 104)

stems ascending, quen; leaver qreen, thich; fower. white. (arvichesfor MRDL cample 105)

tre 4 m.tall. fruit cluster vial-oblomi, flech rweet. (voucher if MRDL samples 500,501) 


\section{Marshall is.}

7eh.8 - Ronychap9 9 ht

36455 equabita maxima L. shentanewer awind village

56 Cavia papaya $L$

* ammon arrend village

5) Cinum asiaticum $L$.

i planted avind rillage

same $-3 / 4$ mi. wi. of willage

58 portulaca samonsis v. Poelln.

on sandy tril in qussy

opening in crement plantation

59 alea

60 qequing on soil surface.

on enoded cral enzemerate

7.i. It nean hightide level on lagron if b shere

a numal lots. Feb.7

44 - me lenge hermit creb found in plastation

2 ghost cumbs from tof of sand sidye almp lagom (necterme) sevenal coentict forimed eating Pandamum frunt wt Irp of lagron beach.

5 - I pawshrfhers atcronted to ligt

6 - antr frem quswend. roveh frem qurund.

fly attracted by swent ( abundant and very persistent)

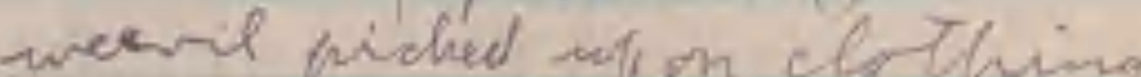

purtute extensin min: leaver fecehed with gray: berwens wange-yeders. twe $3 \mathrm{~m}$. tale fothen much talle, ) ferwen cueam with fevwer white ercefut for firfole filaments.

baver fleshy, wat enlarged fleshy. (roucher for MRDL 107)

Bind, seen $T \times Q .7$

sevinal chichem

3 moddies flying out ts sea.

3) Tunstomes sean on south beal.

truard earenum

$\checkmark$ moddies and 2 trumetome. flying wes lagor.

othemis bised wre consprouraly absent. 
261954 Marshall ts.

Fel. 8 Rongelap islet.
along the lavom the wich platfrom printe. fn some distance wert of village at about $1.7 \mathrm{~m}$. abere Lowtide level. It ends in 4 terraces, very nanow, at about 3-6 dm. intervale vertieally. The wpperment terrar scarcely shows in incepeaces, lveally series of beach. wh difping away from lagern.

The mangins of the other terracer are smewhat undercut and the layers they represent are evidenter peeling off as undercent in eagorn wares. Zhe seand frem the top is leat and finely pitted. Ho thind $i$ very rough the evwest is uneven but edger and partrusions This ervest ed hy ahaxion. with an algal fin. Th thind is darle quen with afine alqal fon. The ture uppres one are the usual blue-gray cren. Few a nimale of buin sont are in evidence of this

$$
\text { Rompelap atoll }
$$

time $(9: 30$ a.m).

the is a well dencelped

sand ridge almy the
lagem shere.

$\operatorname{sen} 9 \frac{16}{6}$

$$
\text { Baq } 306 \text { is a }
$$

beath-rock frim the landwand oliffing series

mentived on $p .24$.

7eb. 9 - Eniactok?

Inisetols mears long island, Kabben?, means main idaw Boch I a Blel.". sand wand ace Matan)

Lagrom beach on muts pait of islet lined with, old beach roch, much eroded, in ficacer well abne hiqh tide cerel. Back of the beach her is a double beact vidge perhafe 3-4 m. hingh of Bag 3/0 is beach sand ermthe lagm beach has. Baq30g is beach sarl bain the seaward beach, the finer compromenf, only, ar fromplace of heace it mavis Is crarser with mere 
28

Ronqelap atole.

29

Bay $30-8$ entains

revesentative material

hereral kind of prumic veach.

$\therefore$ of sand abrie a very mugh errion ramh ended into remnints of a potruding platform.

In the monthern pant of the iseand there is much grasy teriain with sfarse coromit of Cindia, the patches of Cndid the cremut base. of lange quantitie of

treach on the seaward

- ver seaward heach

Almy senwand side is Rcaerrla scubl with scattered Pandanu, edqed with Ruriana. mist th the latter is dead. The Pandanue (enma) obvirusly wehroduce vequtativel, ar in sear 4-5 mitall the bases are enneted by stelens a fort 120 .

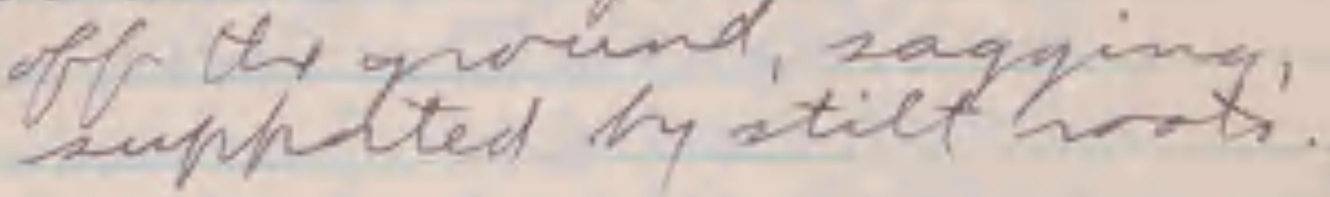

In placer to platinder mondes frm inder hightide lerel. $4 \%$ is very sugh, hris spall planes soutimkacin much fitting and undercutting and ollepise.

7eh.9-Enizetoh 9sect 36661 Pandanus tectnins Pous top of seaused beach cermpof small trees connetel hy "stoms", hrigental stem held abmi quind hy at nots; header qerbise.

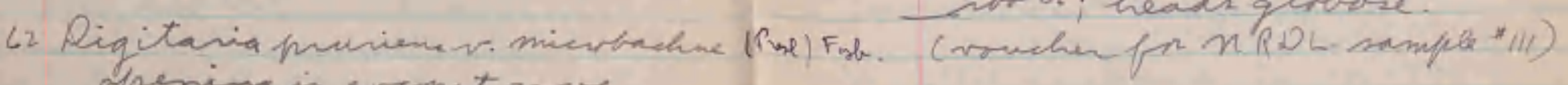
opening is evemutgree backof laqom beach 
$30 \quad 195^{\circ} \mathrm{C}$

13643 Portulaca lutea sol.

opening in cromut yrve

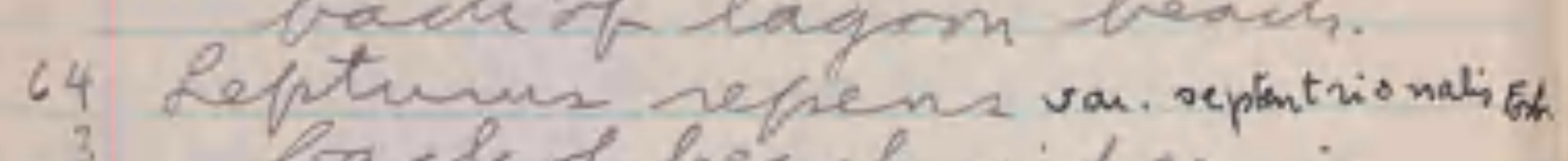
ofening in cormot plantition.

Feb.9 - Kabelle blet tand plat bach of lagom with seattered Seaemer. quettarda, and Messerschnidia fushes $2-3 \mathrm{~m}$. Tall, with bare sand between with a cmypicums algal cunt, seattered trift. of Leptum and a few fleaint of Breha blemg-oral gevsy, leare pink fermen) peante notably in-fected by alougo. Inoperizf ont ins abriniant plants of anrthe form this with pointed dullsurfaced thinmer leaver and white ferwen - B. Affirso), plante less infected but some

4 infection apparent.

Y repharent hivid soen.

mainly qrassy, with manainly grassy, with no live ones seen.
Rongelap atol

31

(wowher ifn NROL sampse Asp \#110)

(wrucher for XRDL sempli 109 )

The eremut trees are ven yellow. ? 2 the conthlifant is rather lemsit leapless surbended foret open mesterschmidia guetarda fcaevila sallax cmmm. ercall. gownd cover of 2 species 7 rimmpetta, lically 7 imbintge: and a very' little portulacalert used to be the lagom sicts shore, arthere ma ligh depresidge with at The inide sand flat with scattered lusher the lagom. 


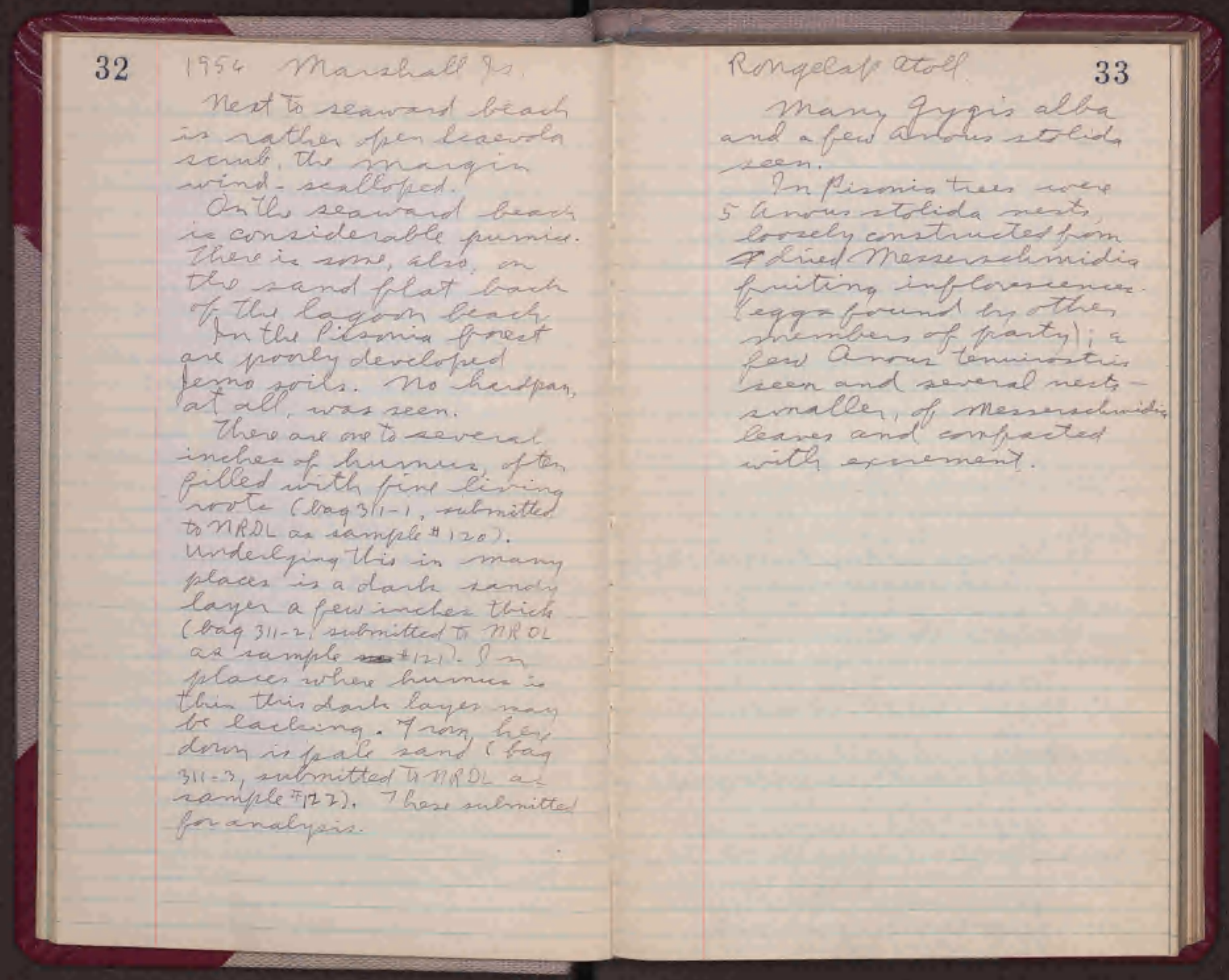


34

1956 Marshall 25.

fitit 9 - Kabell Islet

Ronpelap atop

35

opren zand peat with attered busher.

- 366672 fefiturns repens var septentriomali

$\checkmark \quad 68$ Boenhavia tetrandra Forst.

$$
\text { qenenally emmon on isiand }
$$

$\checkmark \quad$ a Albug platensis conminey irfecting Brerhavia Tetrandha (\$3646)

70 Bormavis Joen hirming forest. crmmm

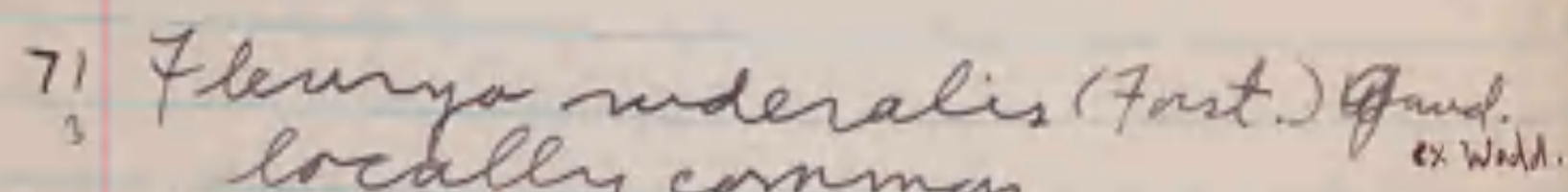
iscale garnimas domintant thee

Fil.

fily - plight wer prestern pout of month vef of Romplerf-

quien islex - seawand thind is Primia frest, the rest seem to be a scrub feres with a ferw indated cremat her on layom zide.

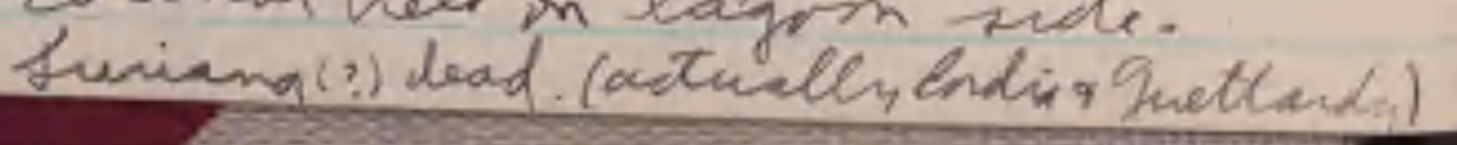
tupt. (uncher for glowy ahmiflenver fink. mesulpant - pectey wish NRDL i amplet/15). tor

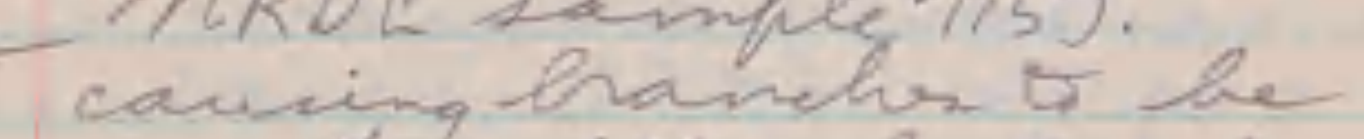
ereot, wies semstemed

pupetiate, leanes dive

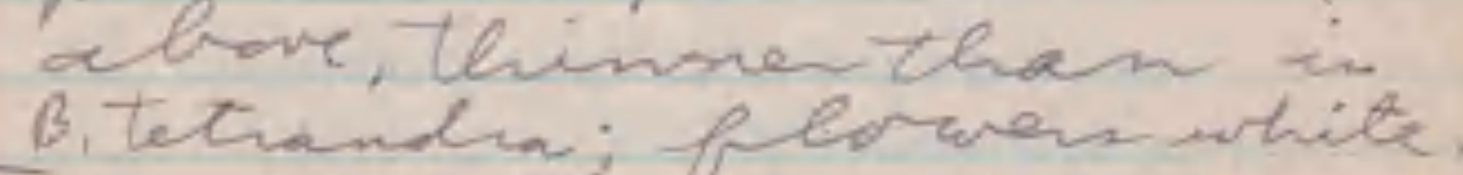

evect, stems veddish, plargess quenish

shrub $\mathrm{r}$. Tabe, ferwer quen (only this me seen ferwering, othere wo to ro m. tall), almont bafless at this seaton. (rovehen for NRDL axmple //6). next isber ineyt-Learrola tamb nith acattered piemia. herenal creanats on lagrim ind One of islet on leesrand reafkeach ream but much Another leerrand iscet 
$\sqrt{36}$ has typicn wich secent shape but with two cunthan stips just to There are possibch remmants of viatirm but shoved be cheoled on a phrt a

sonth of in eart reef sonth of Eniactor ove sand spits with ersion rmp. somewhat vequtated, especially weny lagnn shere. in thelatght moth of inqelaf 9. have ensidentle peafuranepred के

Kwajalein atrel fom Lecnd heak in reef a small of Rocect sand-hanh well within laqum opprite it has a considerable or plem of triangular or rhaped reef patche inside but not quite so reqular as that inside

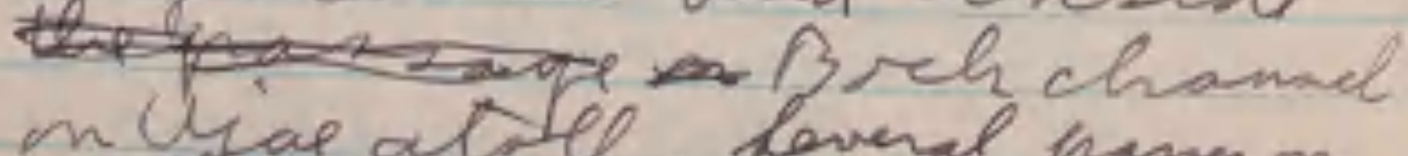

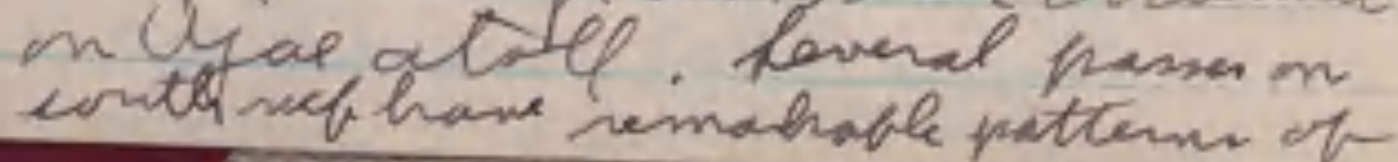

Kwajalai atol

Fel.9 - kwapalein lslet. Lee. Narich chief in public wowh deft. wh. and truch gaiden.

ife sap that a eitcle anmencial fertiliger ho beer used etup nox much hoifhas same sandust and alqae swept forn catch ment (nrstar muscrum?) mised with it befne planting plantingi in raised beds (6 incher). A little conmencial pertilizer before pla nting. muech of algae fim catchment if plant, turn yellow. Fertilize a little when tore tor stant ferwering mules when flase cutling are i" high. when flants are Thin in qaven). Inthe quden are eitrulem vulqais Pasifena edulis lettre, tornatres, juchini, persian melm, hmeyplew melm tumif, radishes, wang bok, surect prtato rcucumber. 


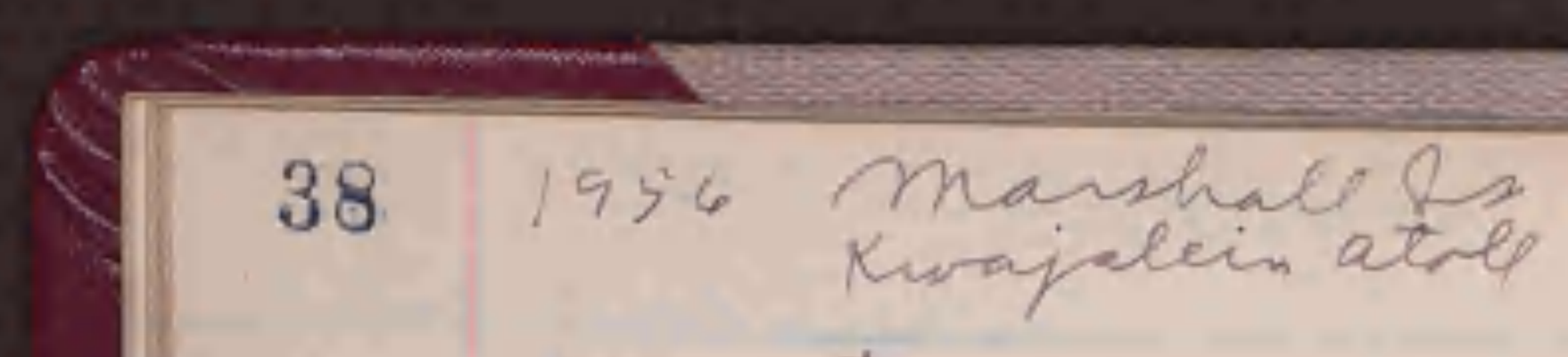

carret, quen mim, pariber, celery, fuimplin, bell pupper.

the prinaghal poveam

nou is the abunlanec

of not-km nematoles

(Reterolen marioni?).

The potants in the mineay

havebean fertikiged a

lidele with commereiad

pertilizer.

Inaclition th plants

licted on $10 / 1.12-15$ the following

reve of semed:

Aravearia excelral?]

"bambor ti" the elengate endyhine noted on p.13.

cral tree" frmaustali cerbera sp.

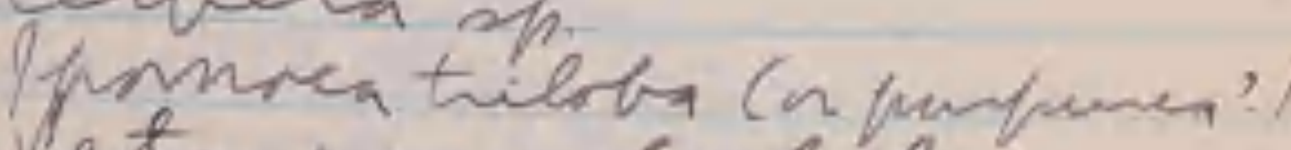

letraea volubilis

arpinian: ("imale-flowered amdire")

Mentimed tus insed pesto: philiphin wad-aner in Plibiffin Mahroang

Ailingina atol

39

Fea.10 - Plying ave atele-meted:

a reef fratch inside the frass to tee left

lecurand (west) sief mangin

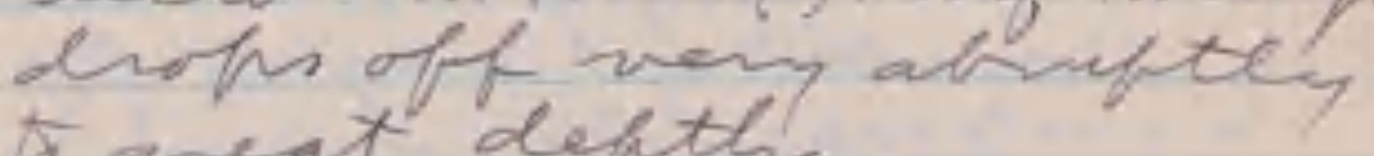

tiveat defeth

qral surgechanmer in soth wef maryin ofprite fips isey. inthwest inner of refs has a oneat eboe finter in eand?) extending

Onthe moth neef nae the midde, are a cruple 1 anall strips of leaching $1 / 3$ the way from lay mon

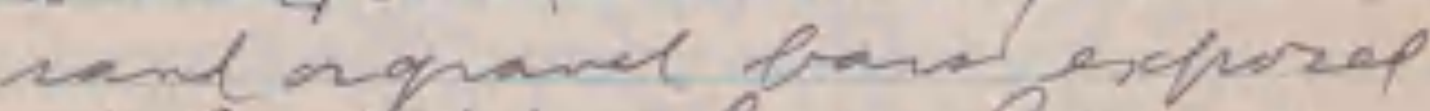
at lowtide almy lagwn mangin of nef, especiall,

$$
\text { the inmen mithwest islet }
$$

has conficuons beachure? almy lagom shre, evosion ramp on outer shore. the euterisect have has an ewsion ramp lut w complearus beach-noh.

$$
\text { corts whe ip } 19+11
$$




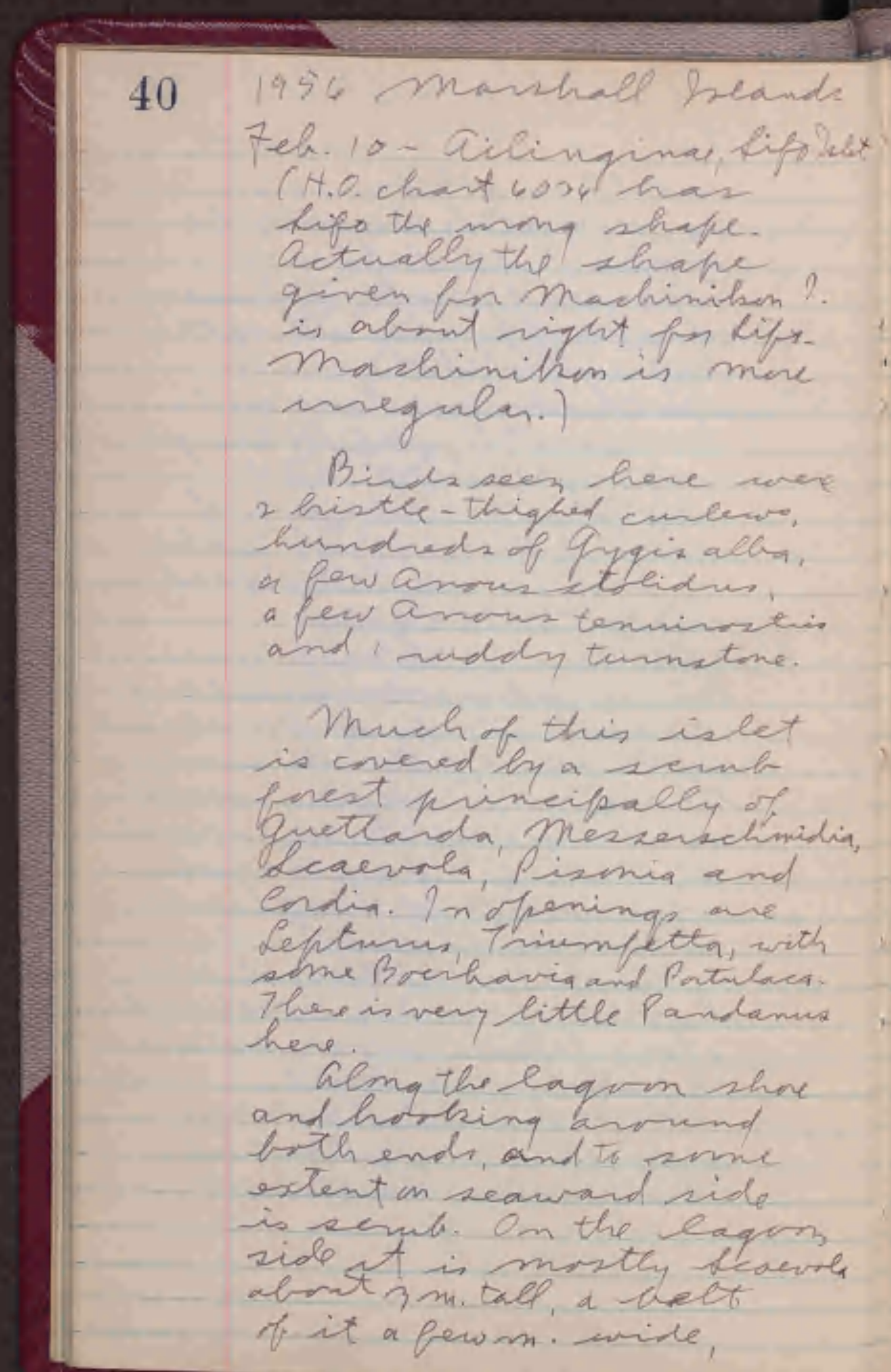

Ailinginas atres

interbebed and denee. Recale, ther is same quetarda and turians interis. Af the end 2 of tho islet the scura is orpen, and cathep it oxist on the pasarawe side, mar wen. on the end ane sume truabe of Luriana, mort of t healthy, fint senve

busher alcolead. Mo Pemphis anywher. $A$ few Gushes of Terminalia

On the seawrand sele $i a$ crifle and hrulden flat, wme of it ofen, sme

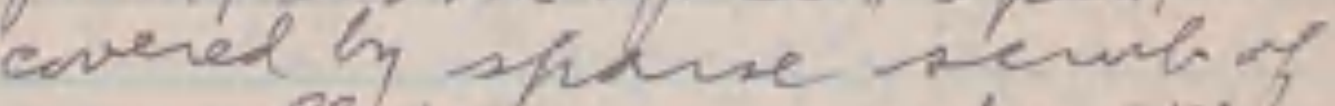
small trees. Undar thers are Flewna an Boreshari tetrandra plants. Zhe

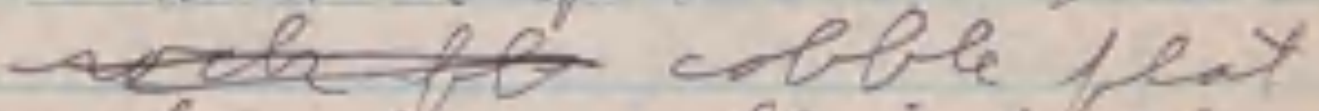
extends well int the tabler fruet.

Onthe lequan aide are plpening witich may beliane sand on quasy. Leftume dmiment bux in olicenect tinft. Home Bocrhamia m 1 lewnja.

on theowten belach is much pumice of thrs binds (tag 314). 
along the east hay of the seawark side ape Tro larye serie of old beachnol, separated frm shme en water at high tide. West of this are rols which seen tw be vem nants of $a x$ old featfon in the last paqes of arvion. foveren, this und mot examined at all carefuel and man well he reef delvis ton hy a strm ont of the hesoch in the web edqe just opposite. otna the laqain ahne is lanqeen lined mith beachloch, mastery mather prish-erring, all hetween tiderlevel and heing endet, especially lyabrasim. Baq 312 is a sample of the youmpest appearing past of this son. Part of the intewin of taller frest of Pismia upto from. talle and endo wit $\tau_{1} 10 \mathrm{~m}$. n mane. Lreably werthe other is manc abundems. Ih endia in adolition $T$ o numen whuread and forming

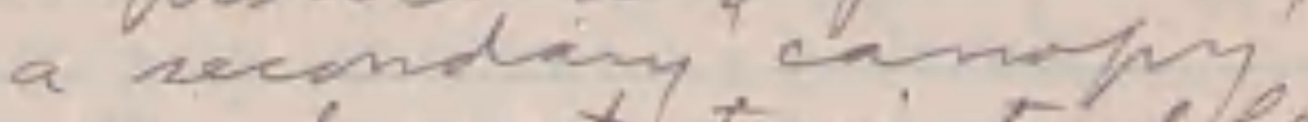
sendi orwt twristeof lever enpncher ramming ons on rean the quand. Clese form a tamyle in placer that is eschanting T penetrate and twavers. - liev is little underquath whene this is Avih, fut in sefe pemings andtein fences Wedeli $f r m=$ a blankex.

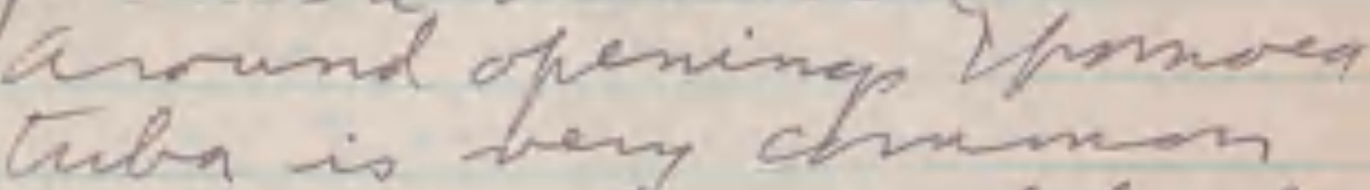
postroming tree and twelos. There are sesteval sucel wne of comennti in torts the subrand the tales Anex. Under on $x$ thes inter taller porert is a grod quath of Mningla splinglacinine Wedela and thwar, thate biqiter, and, is mena? inthe interion is a plamoumad ridge I at sand frut mith a bigh porpution of pebbles in the sunfas fery. The troil hero is represented hy logax $3 / 31-5$. 


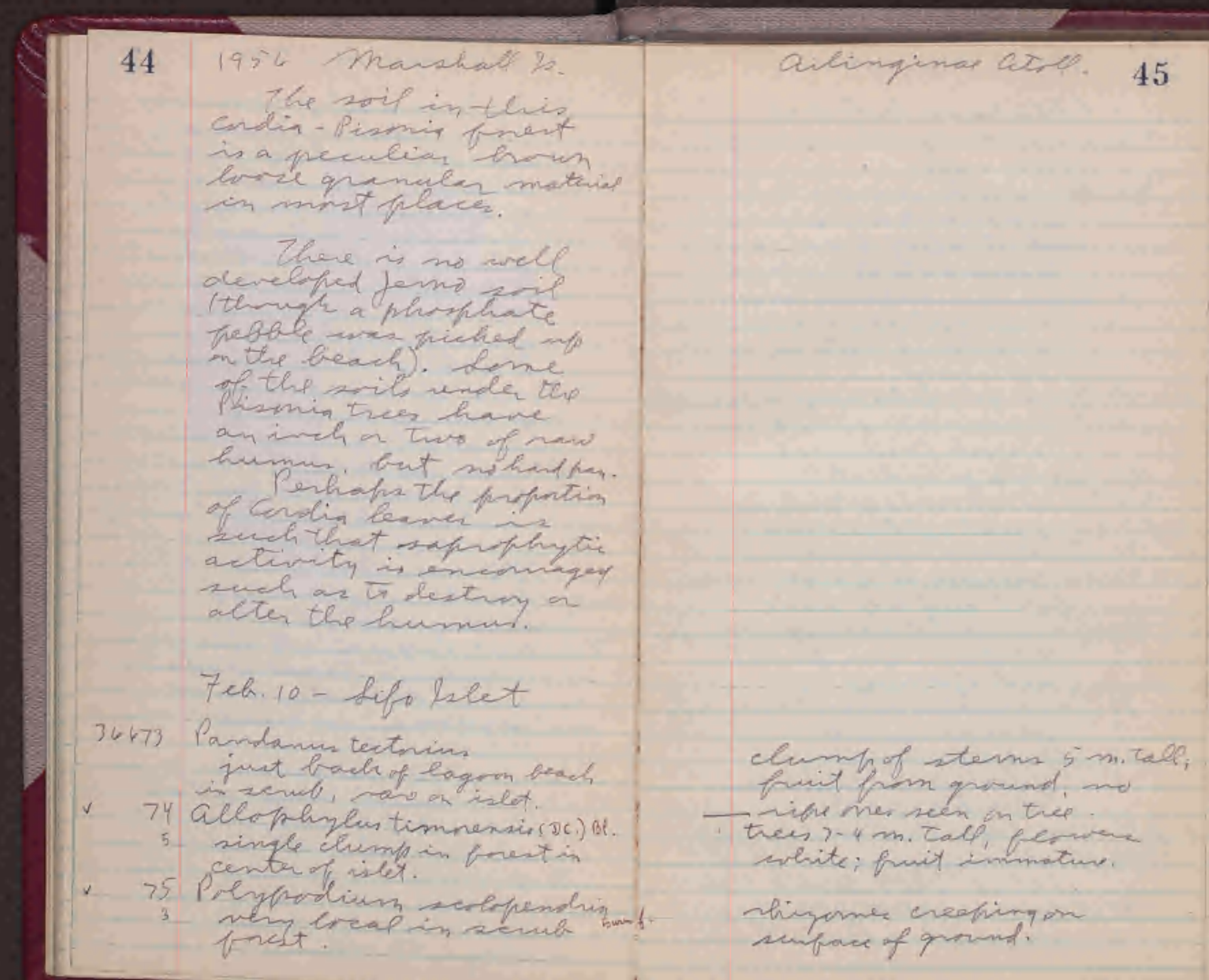


46

Qieingines atop

47

$\$ 34676$ Prtulan ewten sol.

sterns ascendeng.

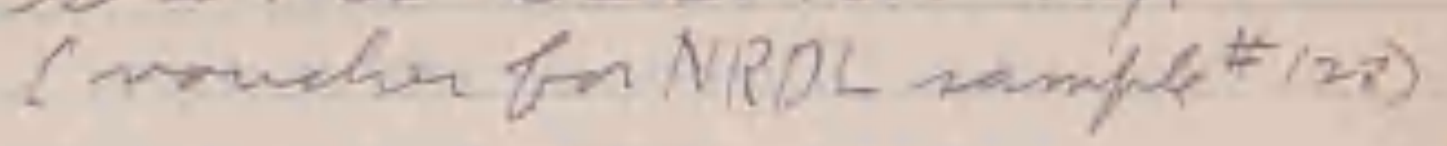

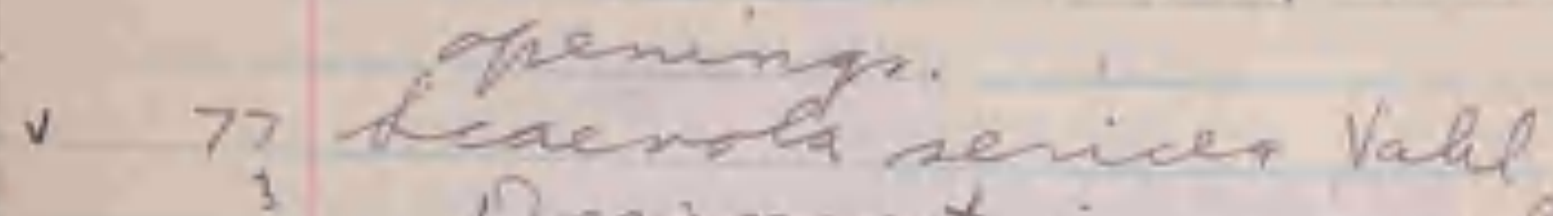
munded bust 3n. Eal,

Dominment in schub perwess white.

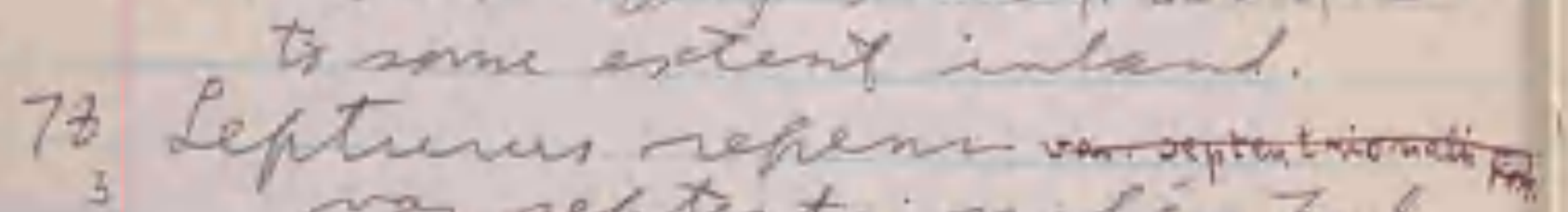
sactered tifft in sers upening

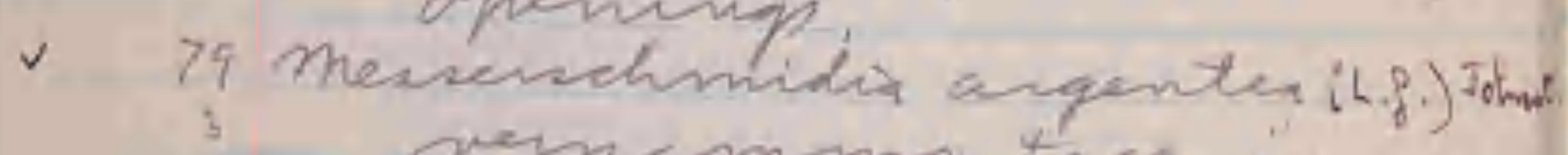
sernb frest.

80 Piamis graendis $R B$. e-demmeny twe

s! guettaris shecions i. emmon in sernla south

82 frivest and all frest.

commoter promin pens Font. cramomin fien prest

small tre 4 m. Vall: leavs feshy) fervers white fravert.

smale treicolers mp is ro-25 mitale), sterile

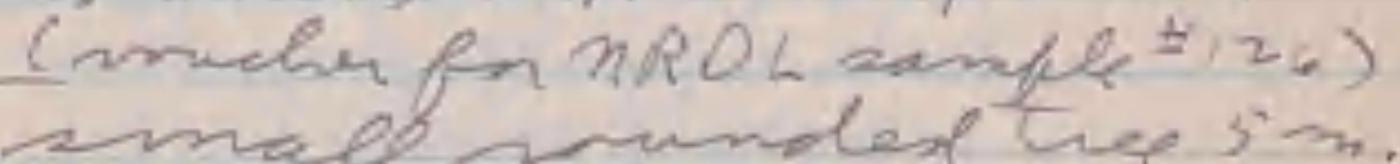

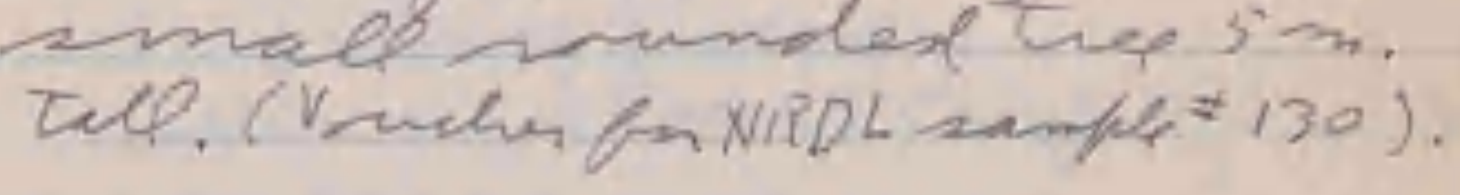
protenate, ferwera yellowi

- 33 Terminalia sampensis Red.

- 84 alfure in acrub

shub 2 m toll.

paranin on Brehteris tethandin $(36485)$.

85 Brerhavid tehander Fonet.f. calsomm oble sand flut

postrate; ferwan fine.

86 Poenpmis ernobarimu(wrucher fo $M R O L$, semplefi27)

(Fint funges wolleded on Ailinginae) 


\section{8}

136687 Mnind citiffreir $L$.

4 common arrund eremut

quave mot soen clsouthere

88

on islex.

(2.)

Pigitarin puvien sas. micerordase vary lacel, in one smats

89 cromin in prest.

$\checkmark$ 8? Cansytha fitifamis 2 . oecasimal parasitic

$\checkmark \quad 90$ Lin guettanda.

3 furiana maritems L.

9! Tlempa underabi $(7$ sima

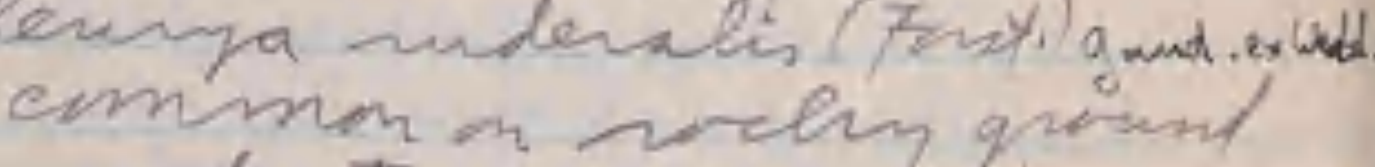
under treas. 79

$\checkmark$ in 7aca lemtrpetalevile (L) o.kn conmy in freat and cremut goner.

$\checkmark \quad 93$ fromeatuba (schult.) G. Don $\checkmark q_{3}$ Wedelia liferna (h.) De. and sedqe of prext?

1 95 endia subeablat cem. co-drminant in forest rvith pisonia qundi. $\checkmark 96$ Temanea impelta (Fout) Rss. dominant in patcher

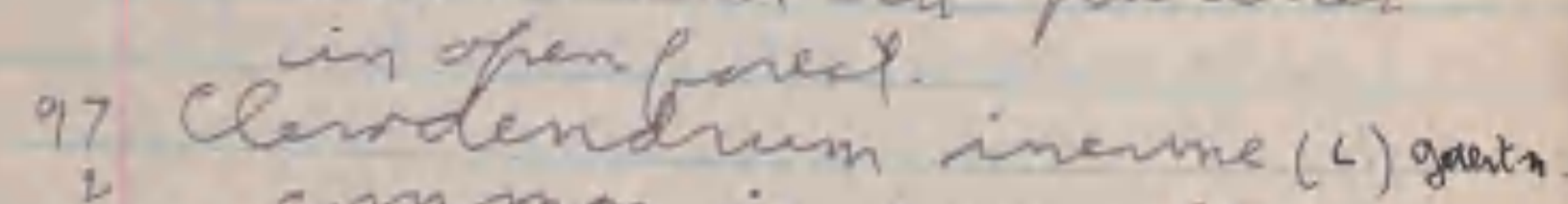
crmmon in amael opening in frowe ailinginat atole

shma 2 m. Tull. ferwes white.

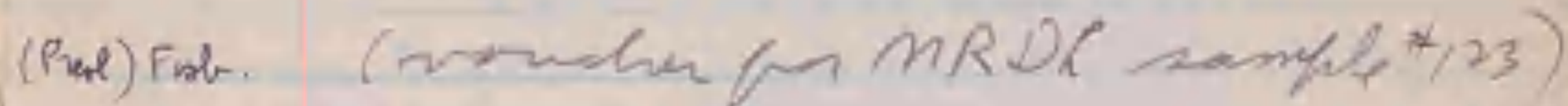

stems quenish yelerw.

shuh $1.5 \mathrm{~m}$. Toll: perarer. - yedew.

stam rad, fleshy.

inflescence of ppecimen fim anther ficant with

twinimy vine, elimbing arertrees.

tangled strmyly rasimnarbmatic herh; hayfer. yellor.

thee lam. Tall, stewil, with elmagte, twisted. tanyed - erwed hamohes.

ereeping forming ense qrewal aver

tounged shubl m. Del, stevile. 
50

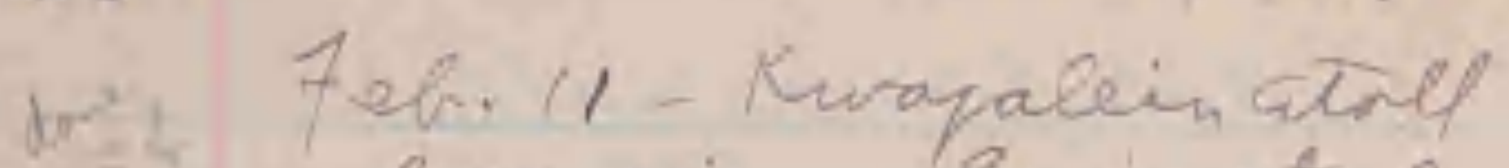

W. + Hom air - Envwetal Pet seems D have chang shape smeathat sine 1952 . It has a shent sentelut W the erwth mew and to be wrighly tiangules. cchech on reant and sely photas if prasible)

Bigej hlex - tho strip acros iscex is amplataly quen now.

Napislexth mastly averel er netante in tangled

Onsanth severa islet tinat ins from ain lihe fawr. with mone als completely encersed laqumlets.
Rongenih atubs

51

7 feh. 11 - Eniwetah stex Rongeis atsel.

trisislet has an emamar sand id $\%$ along tho lagwn beach, up t $3 \mathrm{~m}$. hilg at leat. in pleses.

much of the centhas punt of ter is lex is flead at the tips, the Pismiq leapleas and in fenver.

Bind sea war quite a pew grais alba, two Amorestreida, ene histl-thighed carlew. and two tatilers.

qot a fig beace qecko $1 \mathrm{~mm}$ tho cnstinctin crew whing on sets. rebvilding the radis tatim. They ham liveldryed a vill

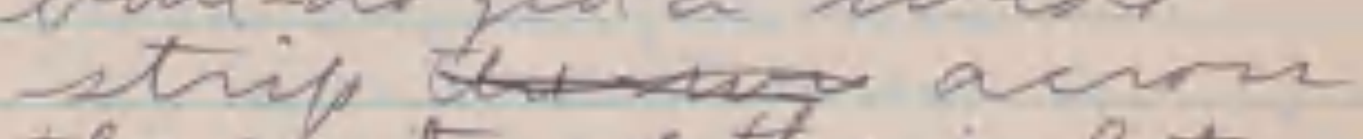
the eenter of the is let wherethe radis station ie being buiet, a ny heve made a rrad the fwellength of the seaved side. 


\section{$\longdiv { \longrightarrow }$}

52

Puanetis a mapied is

tis hmant abrind ant

plant inter baveara.

EnTin mesely de

Onthe saamand sel.

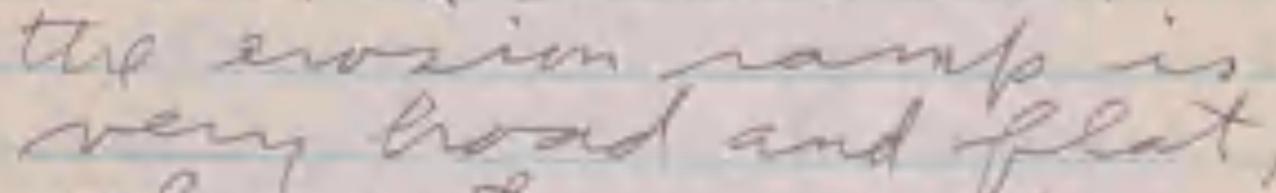

alnurat when demita

tase-lemel. Rublele

tractale en it

CQrasion marre nubl

robes in them Sihp

pritarle but wath ares

and ailt in the brotn.

ane a emmundr beatur

of this ramp.

beach but in modemet

h quantitien (far 3is).

in along the baqnan

Niv seme is an aleswat

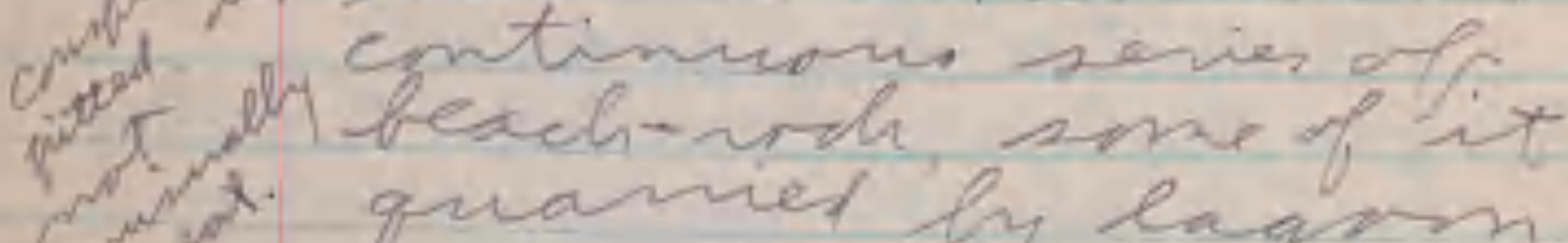

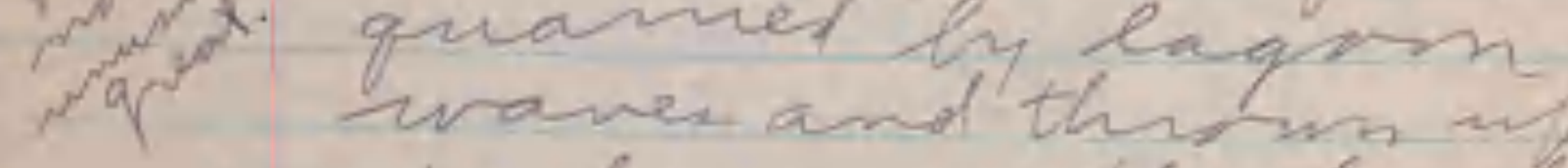

in bealns on the beare? Qut the weet eng is a men thich series of beacharadiphina bet inland formung aliset. Insple this is a vary fonctiva pio with zeveral a 7 ae

Ranperik atres

53

enstiustion of sme ent is goris $m$ at earl $x=$ in the midel.

Thi regetation on th sand vtdor is a mixes scul foret, fren w places.

Pandanus is rave.

the endiefnext - with scattered Pismia - is abrit $8 \mathrm{~m}$. Tell the Tope lrave of learies and terminal hancht aar, a for putting out ravel ifhons. The eadia preat has trpiaceltangled efver liandies, fpen oney wheretere are numbers of Painia, nownderquath exeegt a fow pismia Pprowto and $\mathrm{Z}$ recuine farmaca tuba. There ar many timy endia zeedlings locally, with fem 2-5 leaves, nu tivir mes zeen. thar descriftion, frm eastem half of is $(0)$. Onthe mestem hat of the islet the colis salm mor thenghey dead 


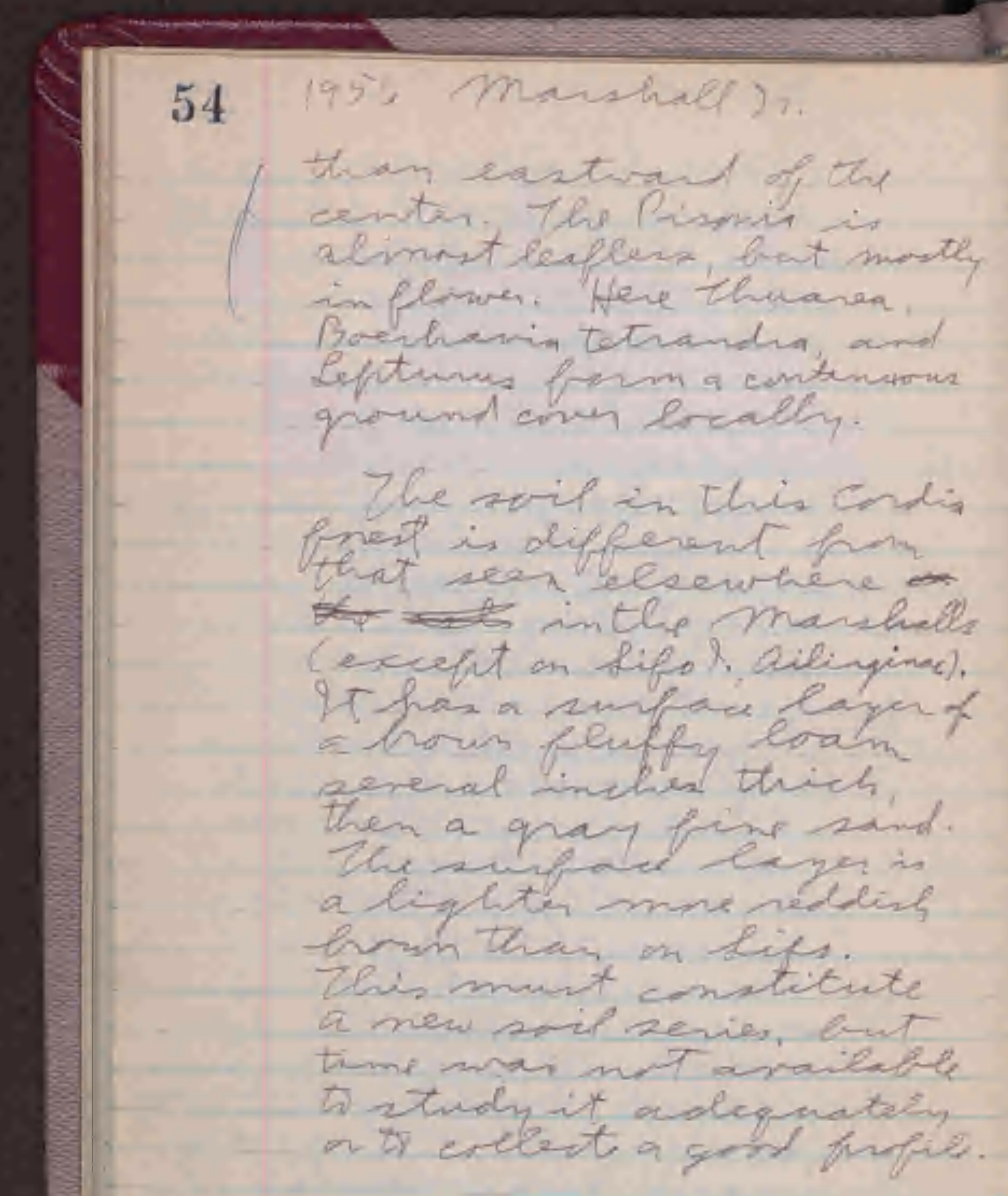

Romperib atiel

55

The west and of the colet is a contivenomo welid lismia finert. tes are prenty develfies Lomosive with no thasplpan butwith 2" of new humeer in plever Land has berw in ave the of ownd in mot placteran tele lorks grite foch: inthe eastern pait of this prest is a dense gromind one of thurea. hrum senffy eram eereal incles thich Ihe a qay fine sand. a liglter mone reviest trum than on Lifs. this must constitute a new sol zeries, ant time unar nat arailabe or to ereet a gent finfie. 
561956 mandale 23

Fel. 11 - Emivetak qsex

+36698 Lida fallax Walf.

verz jreal in scrub fout

heach nidge.

MV

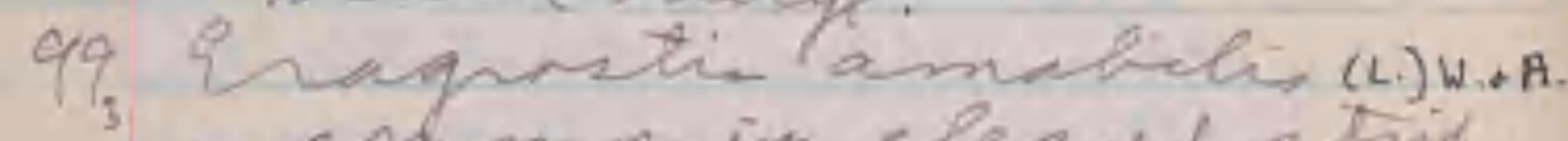

1600 chmmin clearel stiy

36700 Boerhavia diffuen? van.

exmmen in ant arrum

cleared stip, loval sesewher.

$\checkmark$ O) Pisonia quandis RAR. fealeb ofmin in frest

$\checkmark$ or alpugo platensi.

1 parditio on Brenhari

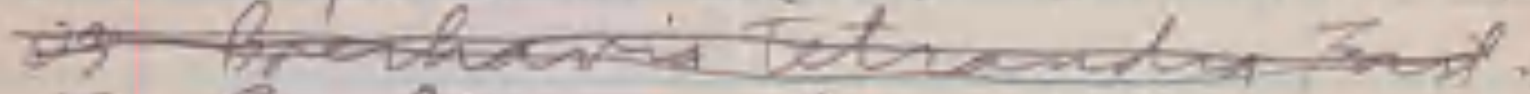

$\checkmark$ ondia subendata Lam. 3 dinimant fruet tra 7 inder thes.

$\checkmark v+$ Thuarea inwrenta (Fonti)R.AS. locally cmimen, foning arawd was

LS Pandanm tectorius Pah. vare in colid prest

$\checkmark$ ob fowlomeq ama ra Lam.

3 cmale aremy ar Piamia frex

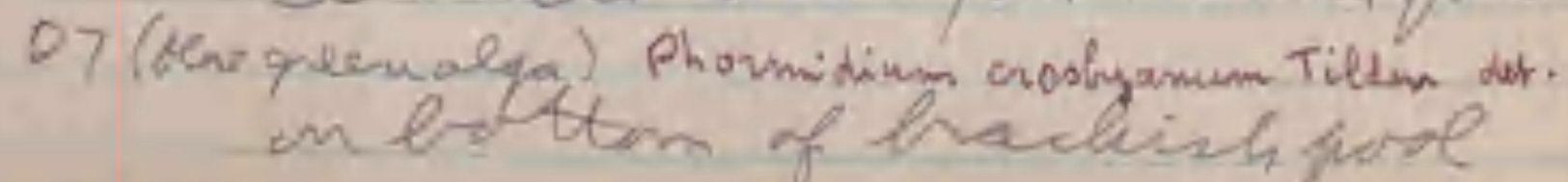

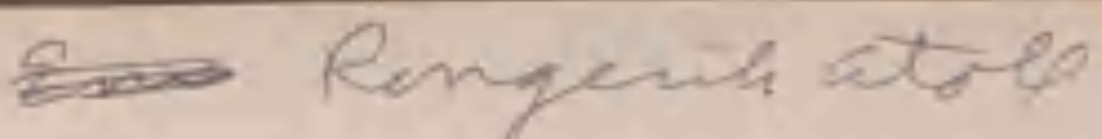

57

shoub o.s $\mathrm{m}$. Tall, fewre clear ange, (and bed in center).

prathate leaver dull veen af nive, white feneats; ferwes white. Nat onipicuruse infecter by alangt. (wober fin $M R D L$ sample

tree id mivel peraver queen, fraquant. all tres. seen wer in fevwer.

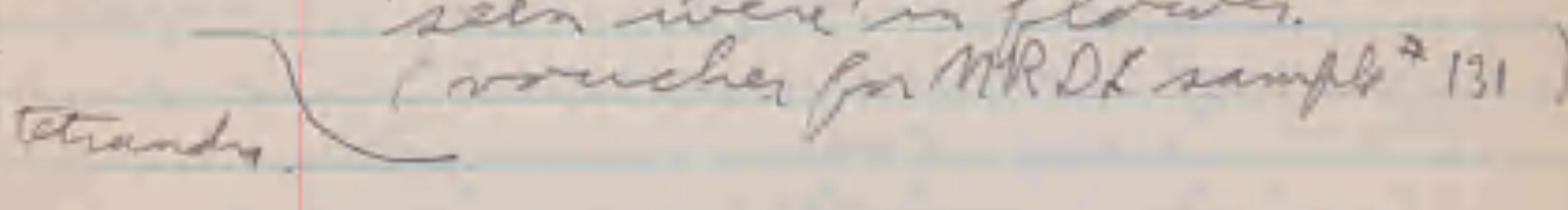

twer \& m. Ta\& stenle: tipe of henches deas

protrate, frmains a a lovie mat. wader in milomple * $(36$ )

the $10 \mathrm{~m}$. Lall, youmg fouting heade qlowase

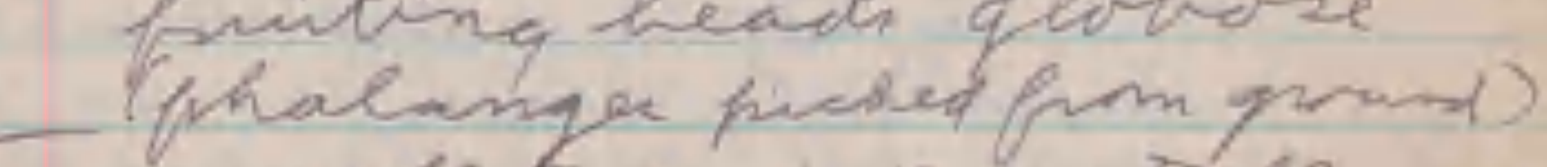
small trees $1-4 \mathrm{~m}$. tal

Dronet qelatinerws layn. 


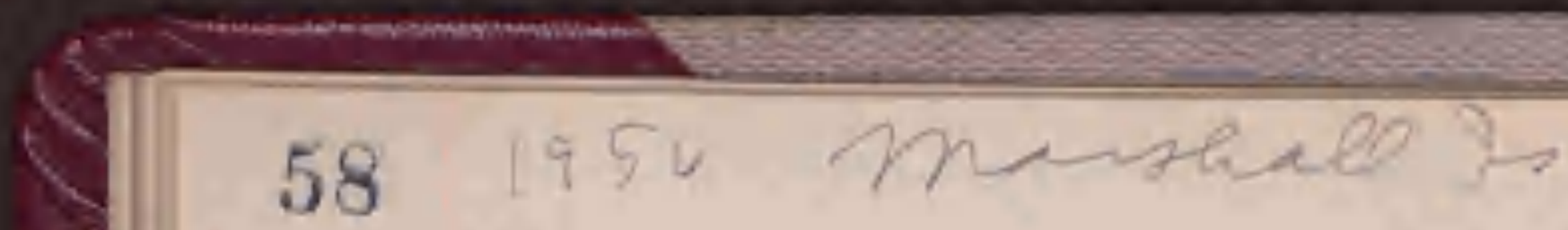

36705 ( $700 x$ aly $)$

onsides af aschist prel

Fea.12 - Kurabein ato Kurajalein blet

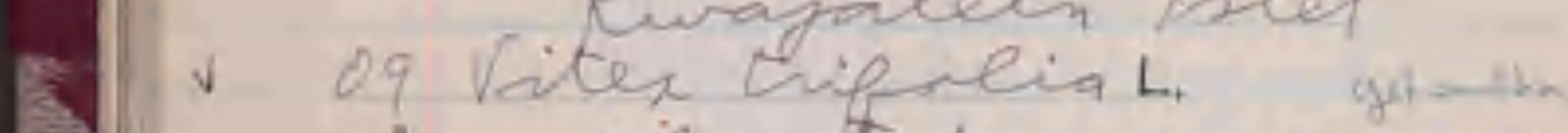

3 pilanted as on mimental

Feb.13 - vitinis atrel winih s set

Jpen exmut land fach

of village in motheant

has scatered Pandamu and onunl-aver prinafiel

of piofitaria, with sme

uaquitis, cassuthas

7 rimimpta, Reptarus.

Fimbistyle, Tacea.

young taeed shent

ch ficht caming wis.

Ame old taw-pits almy tinit bach of villoge with evemutr at least 50 years ed in brtarm. ost there has been much cast of nillaqe but few of millage we area has irytins
Rongerile atop

bingty quen.

shmb w tr, m. Tale eorn leaven tiffaliation lawe onderesi ferver.

Thesis fracticulen ns andelfuch in these plantation - sine scattere" Kile pallax and sereral thiches If indir (minety dea And covered hy ifrmm toba - hurbabe (ampin), Leaenel, quetcalsex Mamy ofthe comut ires henched frum in 195 . typham have turned repat tel tipa and are onowing the then are proter weel urted.

Along a path to south onillaye is planted what appieare $t 5$ le evimum baberi. It has white frower. lober ingerthan vubes, nather crispat maryin. 


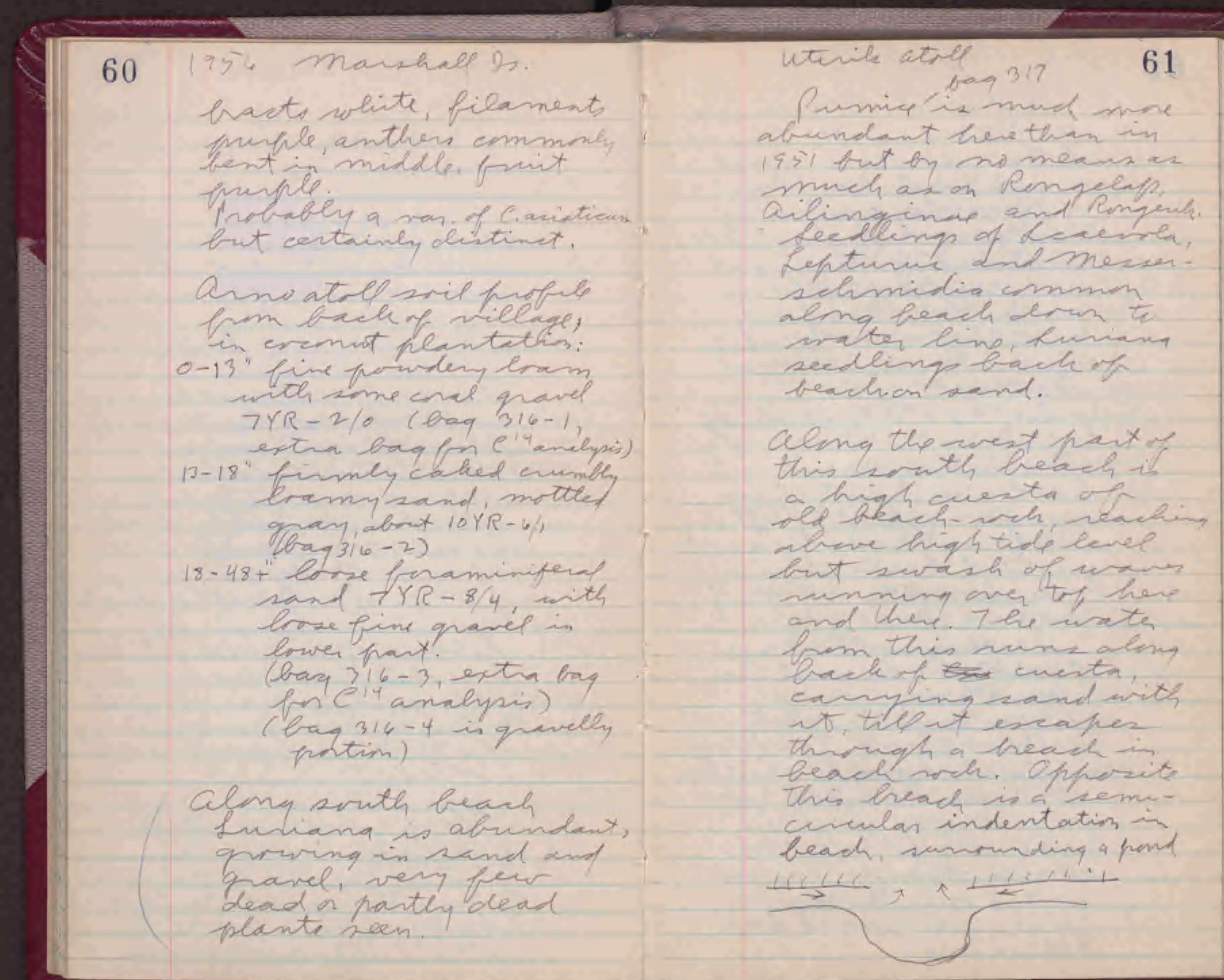




\section{$\sqrt{6}$}

\section{(5) the}

Westural beqinming sbout ewen with the int of the cremut, a queat nubletrat bies lanes foto cuesta, fartiably Wosturang unis thims ory and the vock platferm shours at the curface on the outer $50 \mathrm{~m}$. of the spit. The cuesta has several more beaks her.

on the other side $y$ the shit, the derme ritipe aling the lagorn share $\rightarrow$ borde, smbwhat erwer. mone fimmb held by fefturi anow eassy tha with a wide Ta51. Lame ff the lanper of Westernmost extreme of peantation an spit has trees with very smale with ni flowen. Jew hash on grunh segmof buminat bas. on seawald side of I seet moper is a tern rongl enofin abrasim chamel. capped with a very od laper pis. beach-ridel.
Wtiva atole

Bive, seen:

Leveral gorden plavers

in plantatin. one evested tern on seavand side.

me filover and one turnater tapether in cremul quar

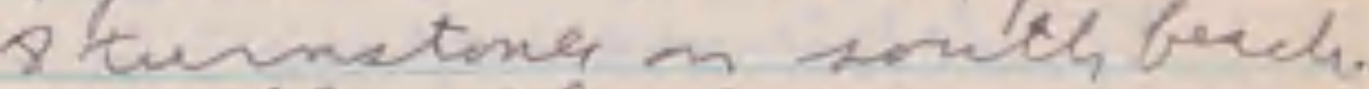

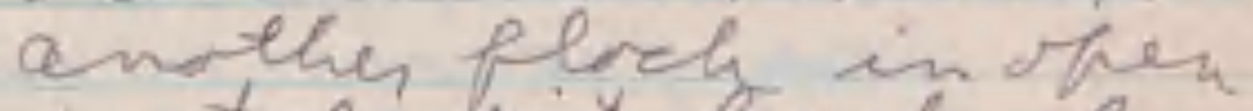
fanter arix back of lapom beach widye - uranleving tater an weble trac on thix peners in wit. 1 whimb Wl? identeres ly call and 3 histlthighel eurlews seen $\therefore$ Sinterin of tpix:

some fige, chichens, an hopl sen, me mandani. young heachpint tress chmon few old mes seen, 2 feer furit almat rife.

I Musa sapientum seen but mat erelected. 
6419526 marchall 2s.

7 eh.13 vtivile slot

136710 , Asclepins curassavica L. planted armend building and cemetery

11 Russelia equisetifnmis shledti. planted bround out building gam 12 Lefturus repens vor swberlatios Fosh.

13 very crmmm on onter beach

13 Evinum bakeri Engl. planted almq path

14 Centella asiatica (h) unk. serval patcher in cormut plantation.

15 Boerhavia diffusa L. common on roky ground in coremut plantation.

16 Bougainvillen shectabitin harely planted arrund

17 Euphomin hirta L. several plants seen nem

18 Digitaria pruniens minotachne (rea) Forb. abundant comprent of round cores in cremat plantatim.

19 Repturns repens var. oululatios Fob. abundant in grund coras in eromut plantation.

$\checkmark \quad$ is Brugniera conjugata (L.) Merr. 3 m sid to in pre thented.
Wairk lsex.

65

corlla vermillen, erown onamg.

flowers scarlet.

flowers white, sepment edgea smewhat crisped, ands acuminate: le ber enjer

- Than tube, filaments pupple. pristrate, rhizemes on supace of qrind.

in coman mativate. stems reddish, leaver dule, - flever pink. shub fleral hacta depprad. tree 5 mitall, ferwens ad. "jong": "friit used for glue". 


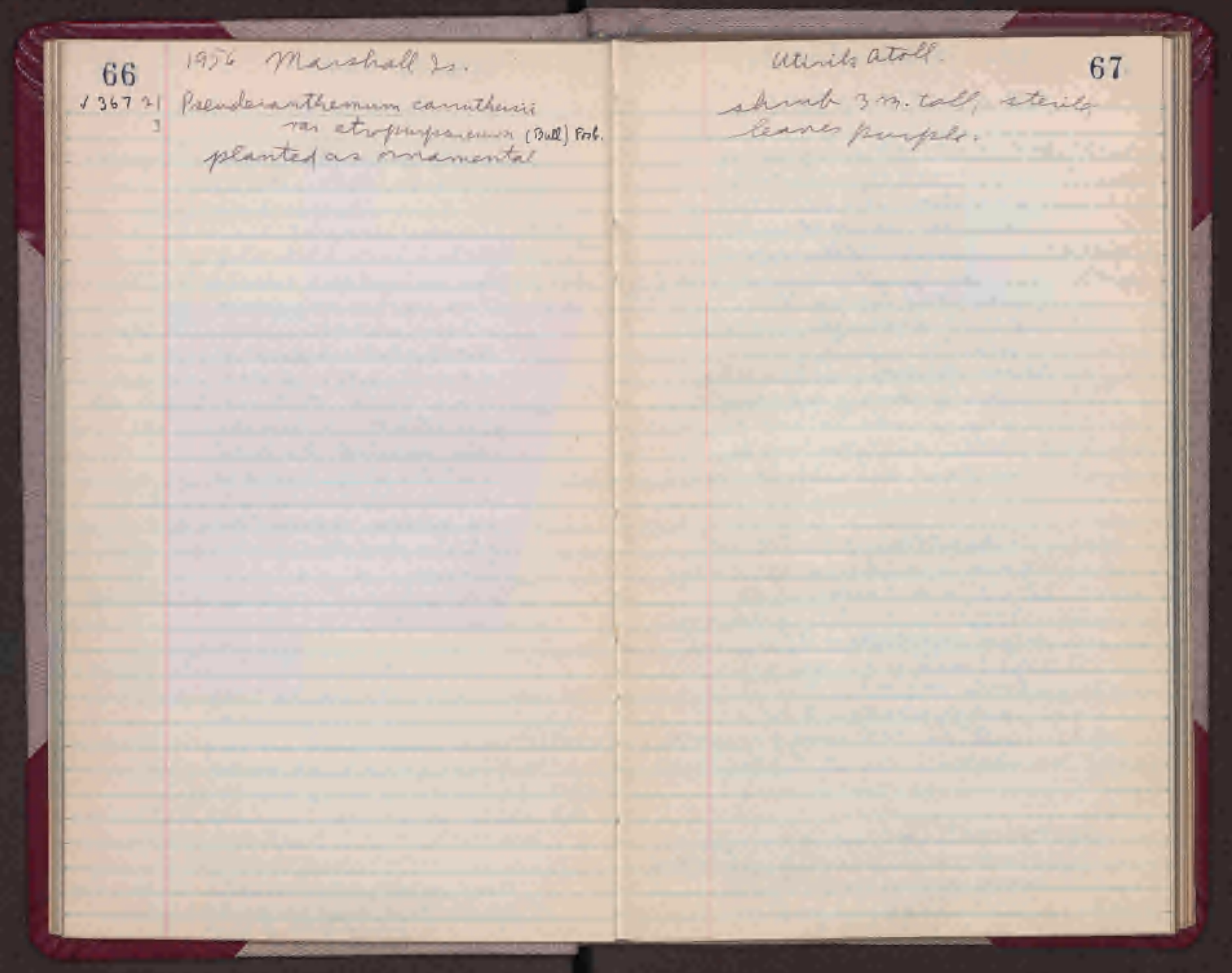




\section{(1) $68 \quad 1996$ Manshall 2s \\ Ackiep atre \\ 7 eb.14 - Likiep Islat \\ 36722 Hedyotis bifhera (L.) Lam. \\ common in ofen creanut \\ plantatim. This specimen is \\ from near seawand sile. \\ 23 Cinum latifolium \\ was. zenylanicum (L.) Hook f. \\ Pepermia obturifolia (L.) A. Diet. \\ protiate: chenotic. \\ planted in pots \\ $\checkmark 25$ Rhves theres (1'Hea) Hance \\ spontanerus, spreading \\ cingorusly. \\ $\checkmark \quad 26$ Cymodon dactylen (L) Pers. \\ in lawn around chuch \\ a heacthy plant of \\ Agare sisdlara qurwing \\ in pot, arhite-floweres form, nat \\ mery healthy. \\ Bind, very pare \\ one grqualba, anous stolida, ar anver teminstiin seen on seawnend side. \\ 27 Hippeastrum puniceum \\ commonly flanted, flrwering \\ peduncle 0.7 mitall, sliglity compressed; flower white with puple triper. \\ erect; leaver fleshy \\ leaves pupple beneath: \\ flowers pink; juice saidts \\ be initating. \\ prostrato to ancendirn. storile. \\ asket Capelli Deßum if any lavera ceront hiseass it ar such. Mentimed a place where eremut trees looked wery pon. Perple built a howse among them and lined there for a tieme. The trees tended to pich up after perple had lived ther fur a while. \\ duncle hrelon; fforesensing wolla pals wamichin, strangly zogmmplic.}




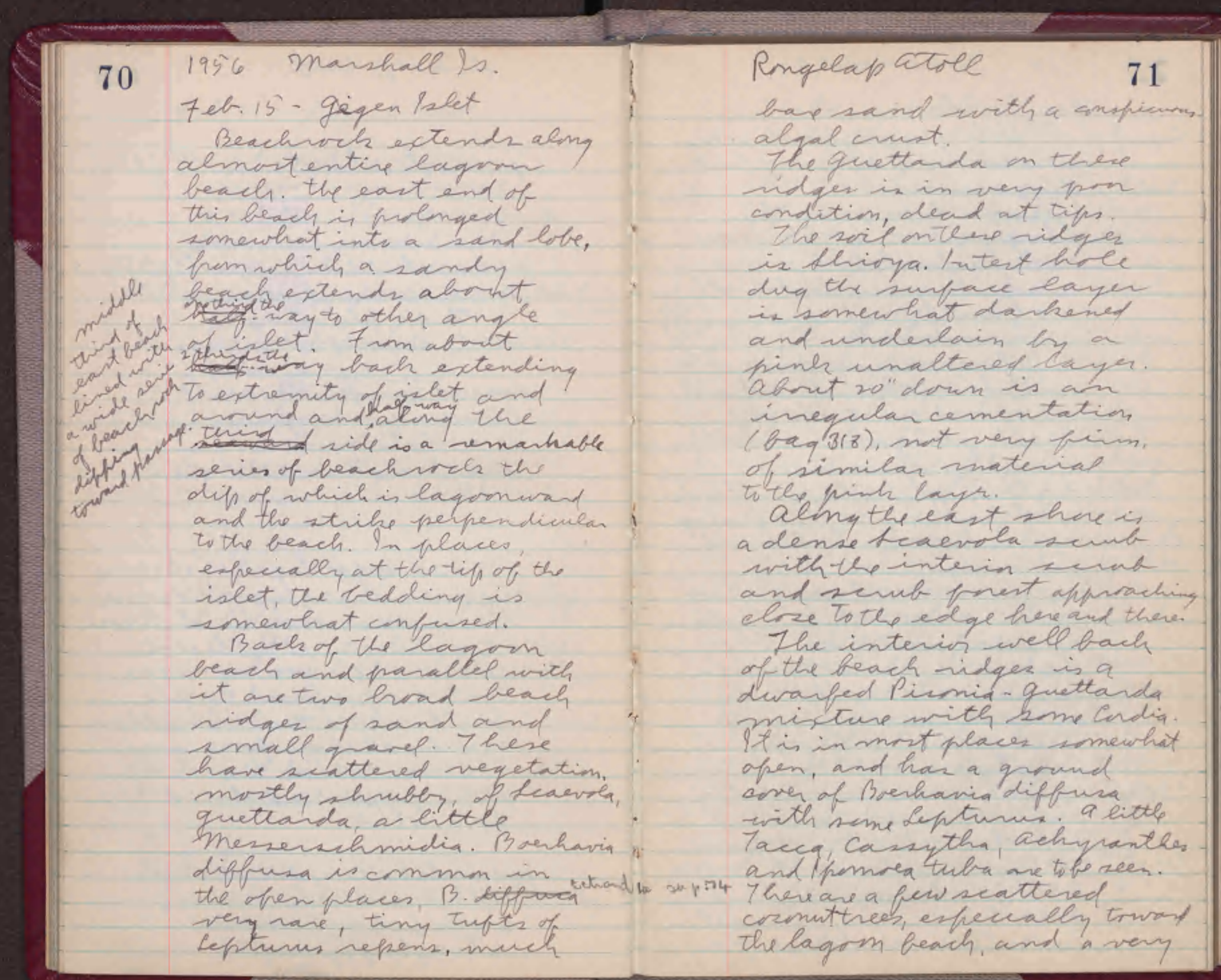


1996 Mawhal is.

few Pandamer.

at this season the pirmis $\therefore$ neady leafless but flewering.

the sail is maste Lhirya but with sme weaken levelrped fems under pismia bux with mo handfren. The whers

Betroen the reasmably well derelrped frnest and the ofen scunb of thy becel indqes is a belt frather ofven seval with Rgaerres quettendy and crntu. Inter ofiening an Putulaid litica and" Reptums.

The interesting feature of this regetation is its curvent anditim. The Lcaerola and messer. schmidia are the mey common unde plants that seem to be in really namal endition The rismia is moth leapless, as wrild be expreted in the ding reasm in thisclimatic folt. Howeres it has clumps of darh quen leaver that dernost vesmble mistletre from a
Rongelap atole

distance. The Condra is mastery dead os almox To. The quettarda in the fruest is lavelended axch fom the tifu. Whe

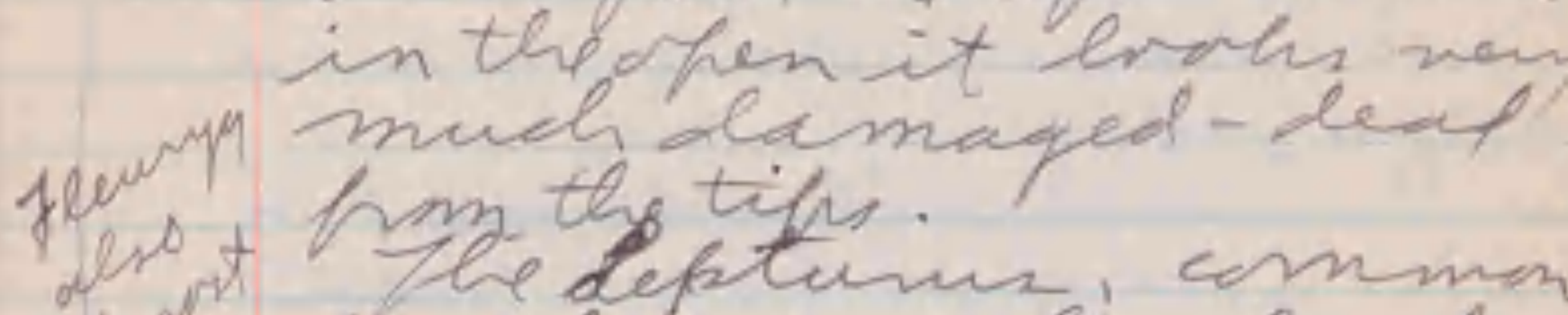
Thedefanus, anmm om facily qeneralen, hack you of the beach ridqes is Intirclydeal ef cefax in a pew tiny seedling tuft on the lheach vidges. fomecormut trees are dead. Lina this iseot uas mort stronghy showered by fall-out in manch 1954, there mary be sme ennection.

gy is alb abundant one golden plever seen. Onabistle thiqhel curlew sech on east share - very tame. Pumire common but not abundant (bag 320). Jemo sil profile under Pismi: $0-3^{\prime \prime}$ naw humne, $10 Y R-2 / 1-2 / 2(\operatorname{teg} 319-1)$ $3-14^{\prime \prime}$ dach quy $(10 Y R-2 / 2)$ selt and pepper oolnes fire sand with abundant and quave (bay 319-2) (erre nat ding deeper) 


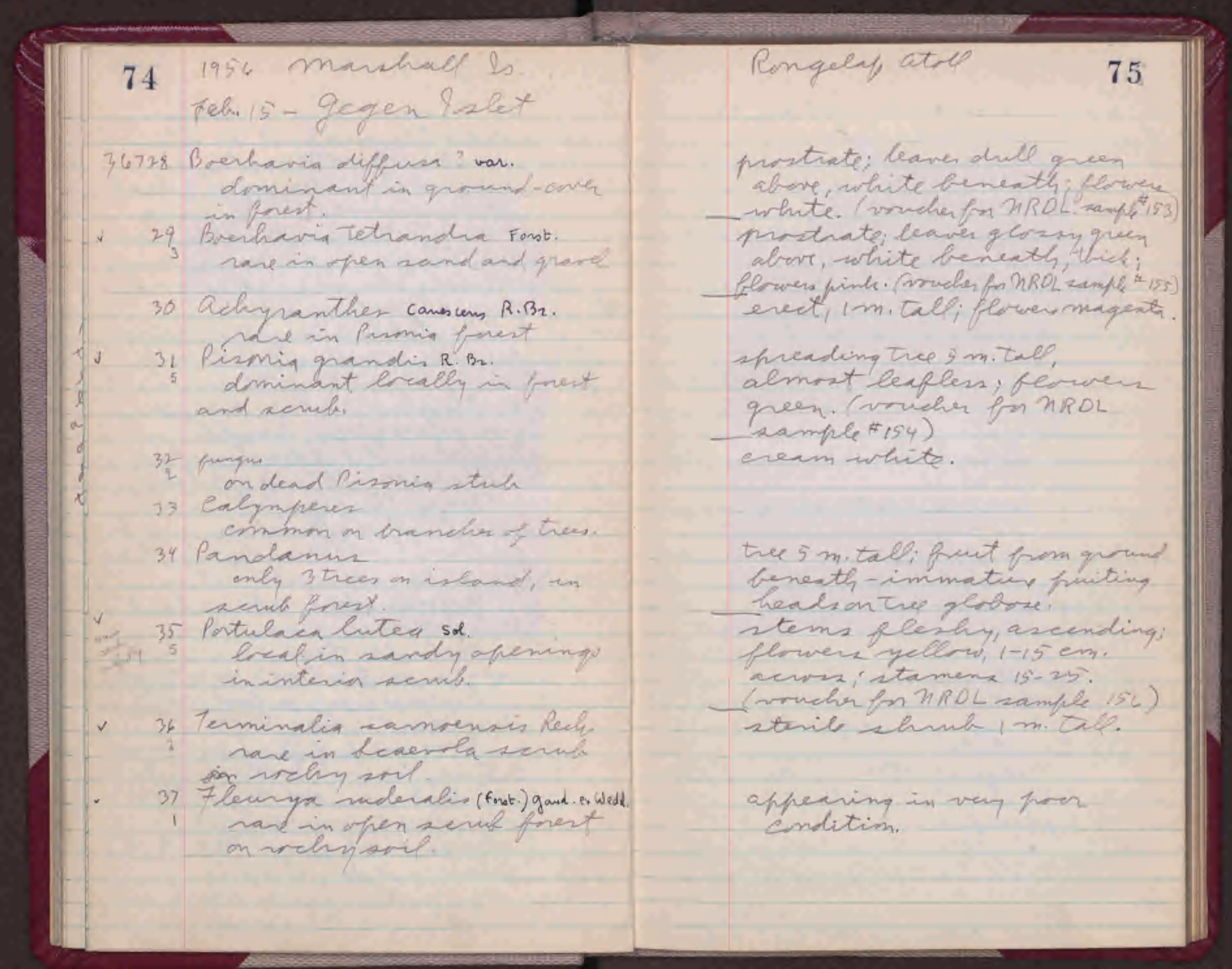


76 1956 masshale 20.

8 geces Crenobits perlaty sow p. 24 ailinginas atel, tiphs blet renthin. Fel. 10 Ringerich atol, Enivetaks,esl 7.h. 11

S9 insests athrected to light.

10 in village (ant, an ground in eightel ewnse, frat

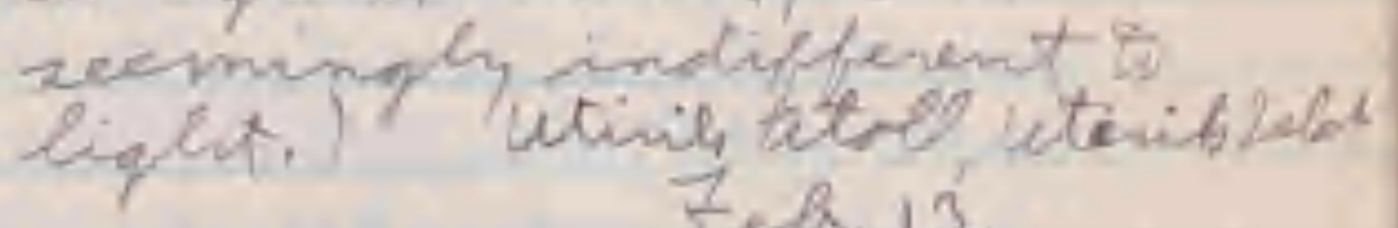
Fea. 13

12 Inserts from Piomin truenk Lifo stat alingina its सA. 10. morequitolarrace in arates in comitin in trunh?

Capasshopper mitrumh portubls merely accidentally):

13 onbravim apisen Lilingima atel, by thet

142 bectles and ling homed

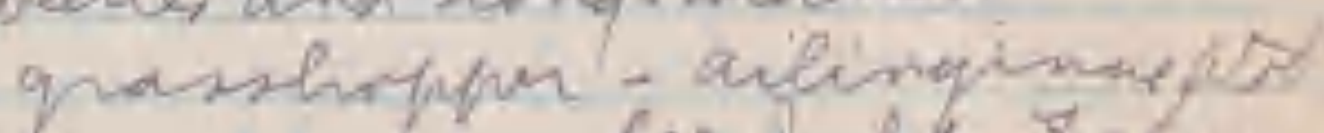
15 Cerwbitg kift alet. Tel. Romqelog atole qiom pax

16 tylerpa sturn a man on harajoleis 17 tee

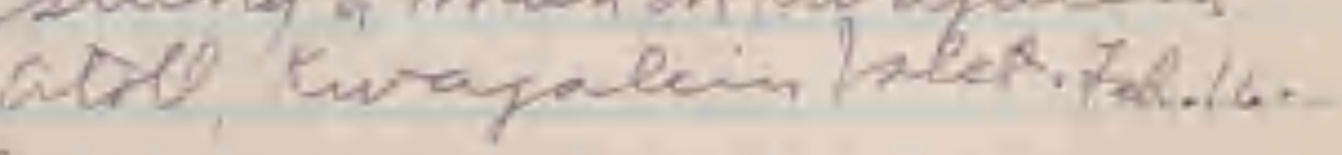

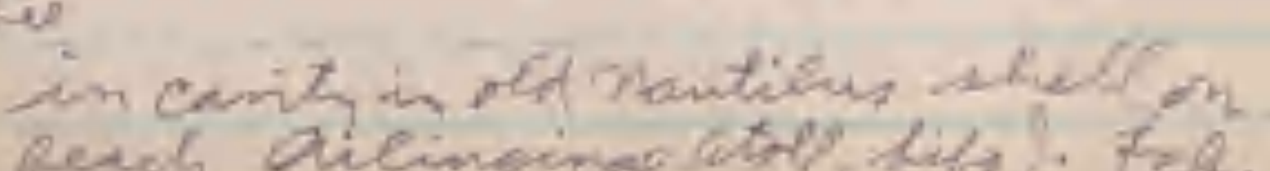


ए

76 . 1956 manshale 20.

Q1. amimaln $\ldots b \operatorname{sew} p .24$ enenobita porlata interin. Fes. 18

8 gecers.

.

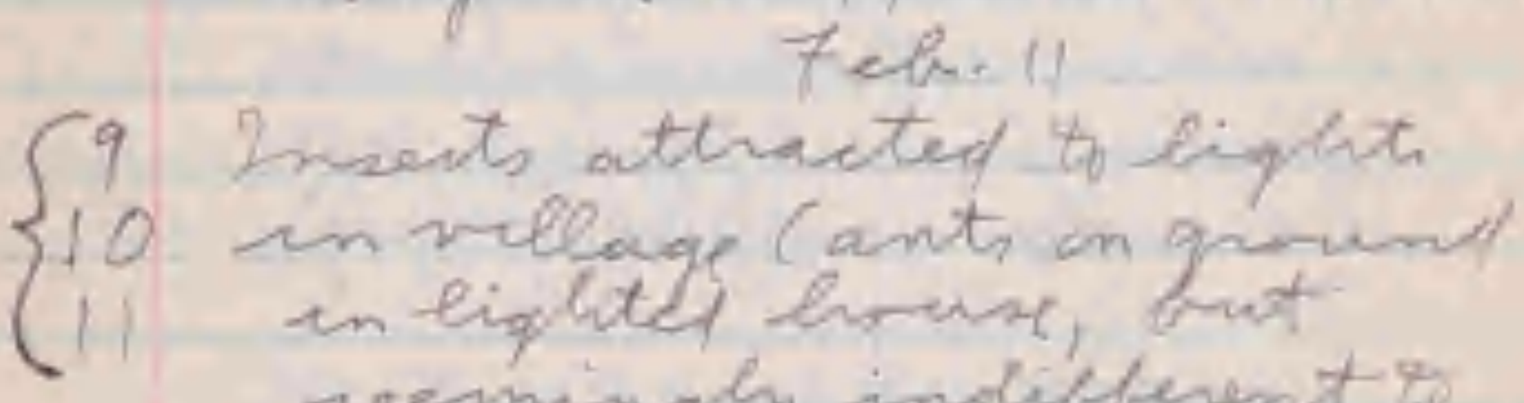
zerming hy inderferent is

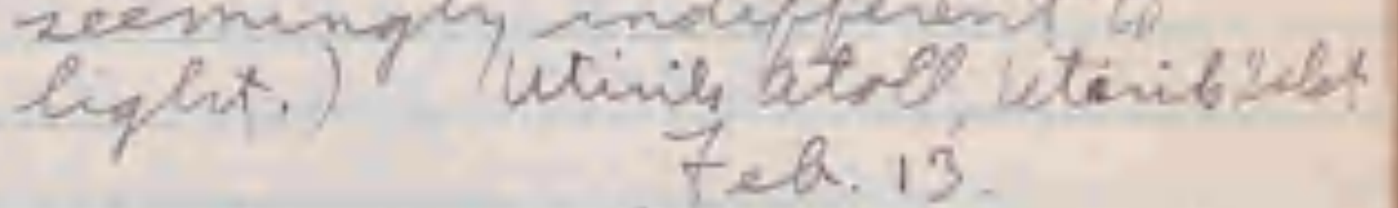

12 Inserts fom Pismin trums Eifs set alinginee ats

(morquitolemas in rorate. in cavity in tiund?

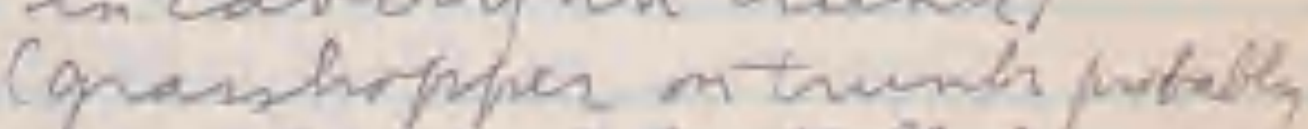

13 ost weaving apida mereery aceidentallop) lilinginatat, fifiblet

142 becter and leng hamed 709.10. quashorper - aibinginmits 15 Gembita atrel giqen 7 - Bex 14 Kylverpa string a man on krajaceis 17 bee

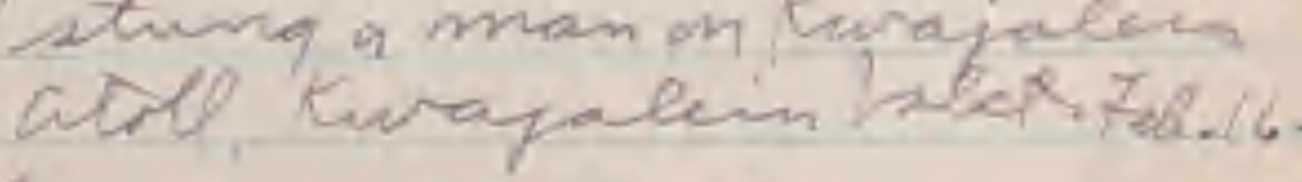

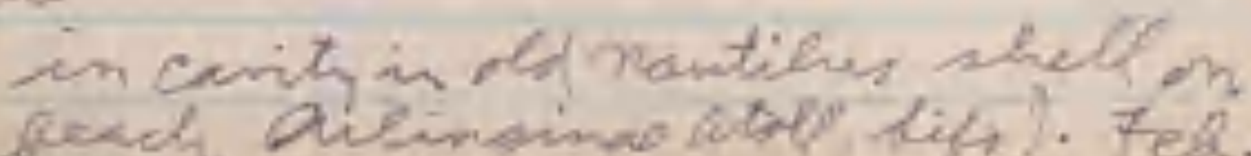

137 38

Wtivilh

139
140
141

$\frac{144}{123}$

127

$1+4$

176

$1 \times 7$

$1 \times 8$

129

130

145

Rikiel

146

147

148

149

150

151

152

153

134

155

Lifo?
Dighteria

Borlhava tetanda

Eeferarar

Pontulaca mavoment

Pisonia

gietcala

Bewhart cliftera

Thuramea

Digitang

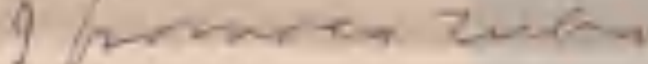

zhereres

Pismina

Berberis

Prtular ates

Leptuma sepens

queterueta

guettarla

Pirmia

Boesharia teteandes

Digitania

7 huarea

Pontulaces samomeis

quettanda

Arverharies eiffines

pismina

Borchavia tetromers

Postulace entes

Beptrums 


\section{6,1954 manshal 20.}

8 Geeno

$$
\begin{aligned}
& \text { crompitit perlata } \\
& \text { alimgina atel, kiphs blat } \\
& \text { interin. Fel.18 } \\
& \text { gecho }
\end{aligned}
$$

$\int_{10}$ Imsests athacted to eigint

$$
\text { tol, Eimvetak 2 lex }
$$$$
\text { 7ea. } 11
$$

$\{10$ in volege lant, on gurn

$$
\begin{aligned}
& \text { zeeming hy indifferent tiv }
\end{aligned}
$$

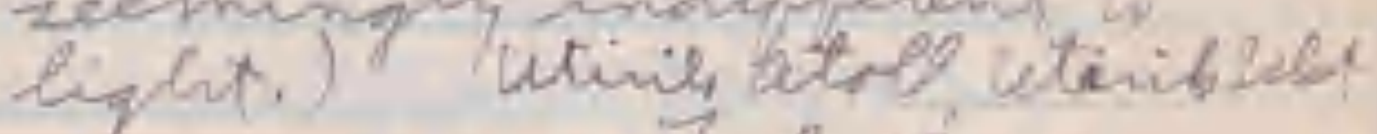

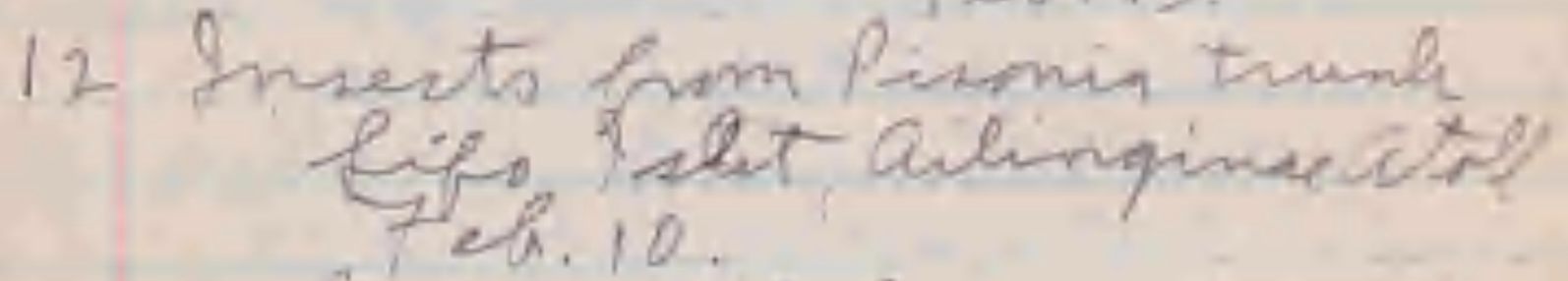
(moxquits lanme in wates in cavity in trumls) Grashopper m twenh portall

13 cob-weraming mish meres, wacudentally).

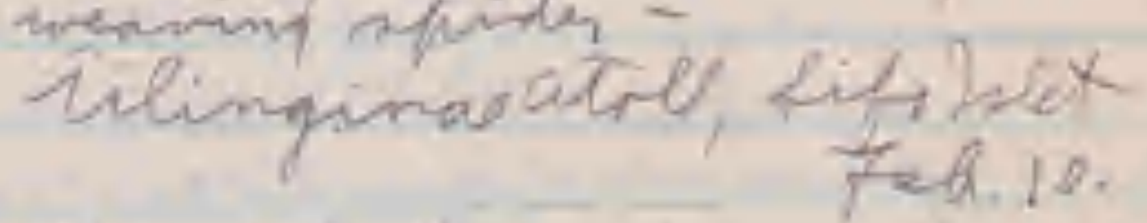

14. 2 bectes and lemp-huned qasshoppen - ailinginosits

15 erenohita life slet Reb Rungelah atrle, aigen zhex

16 Xoplerpa stung a man on turajalein

17 si atl, turapalein lakex.7ek.16.

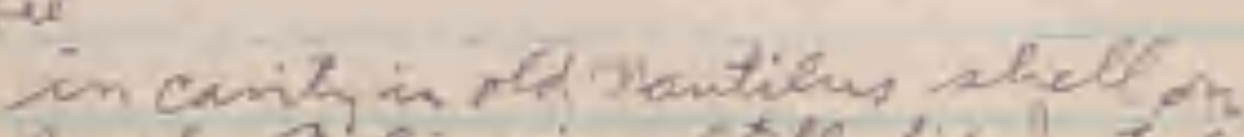

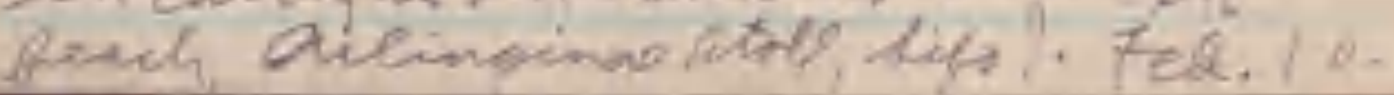




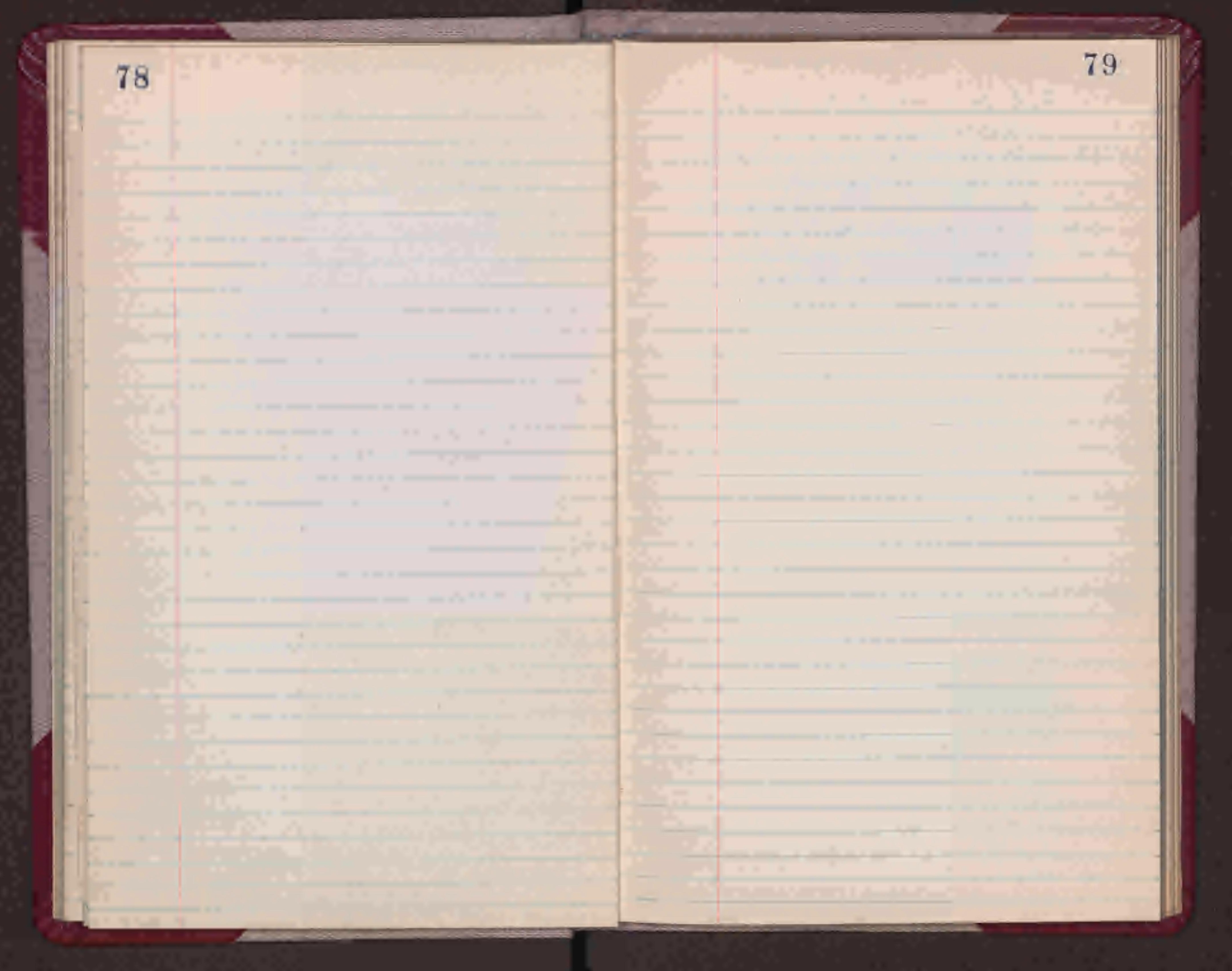




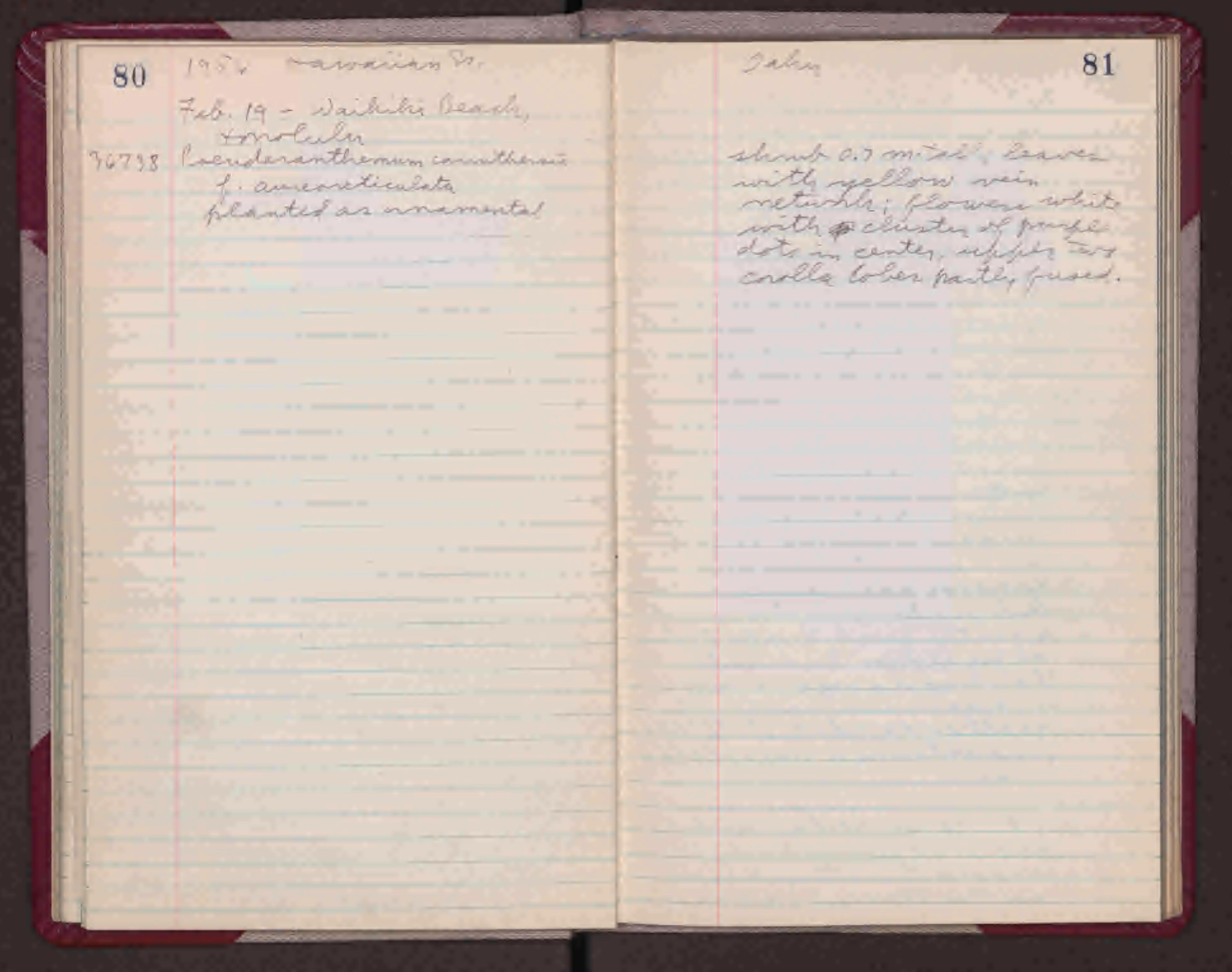


821956 Uc

Feh. 24 - 7 eiqht fmo

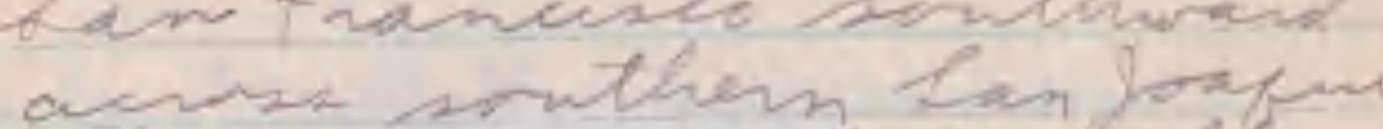
Vably, Antelpe Valley. mazave Desex meeder

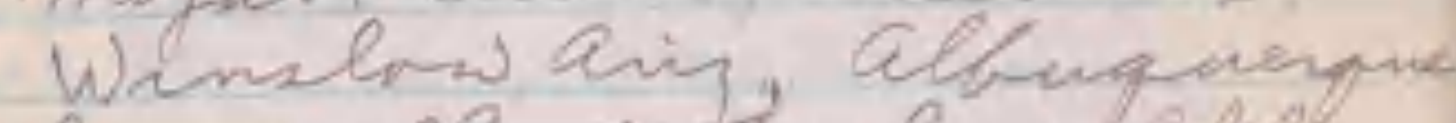
Amavill, to ines 2 bes.

Teven lof pures an tores bevin nanges mash antera wentura $c_{0}$.

Pn Majare Desert are of desent minutain verges forea clueto the histiny Lts and former toperiesy, If tw typical shapper nugred isreated desent ainger. Pt has the cmmm sheletnized from but with remna nto a qenthy avched peatenu on trp nidges. Indicater that trese lange may te enram wemmants of genter winded bill-ble mountains in monatain.

masses.

I mow in laikal area and on sll mountain masses sf nentherp arizns and Hew previas. In abme
83

place splection of sun shants a suppining ampunt of surface wates, evidentey ivenct of thasring

Meten Enater, nea Winslow, has a rathe squarish shape, sen fim almat divect $y$ abme

An extensine bus utum extendr from the Ri, quande Valley pius

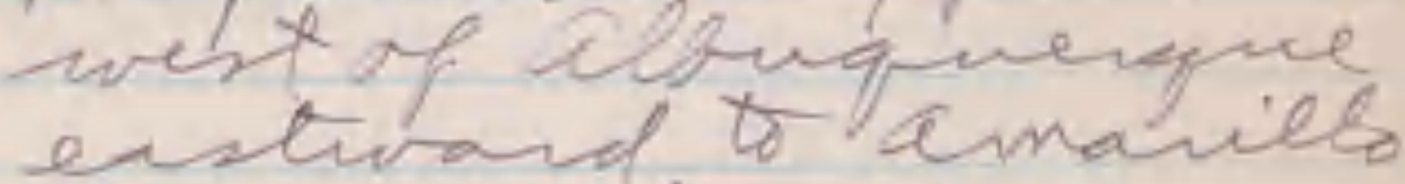
Texar, and then faded rit sut seme lust blining alemat to tuesa

Beantipul example of entremched meander fint weit of 7wesa small stieamr. 


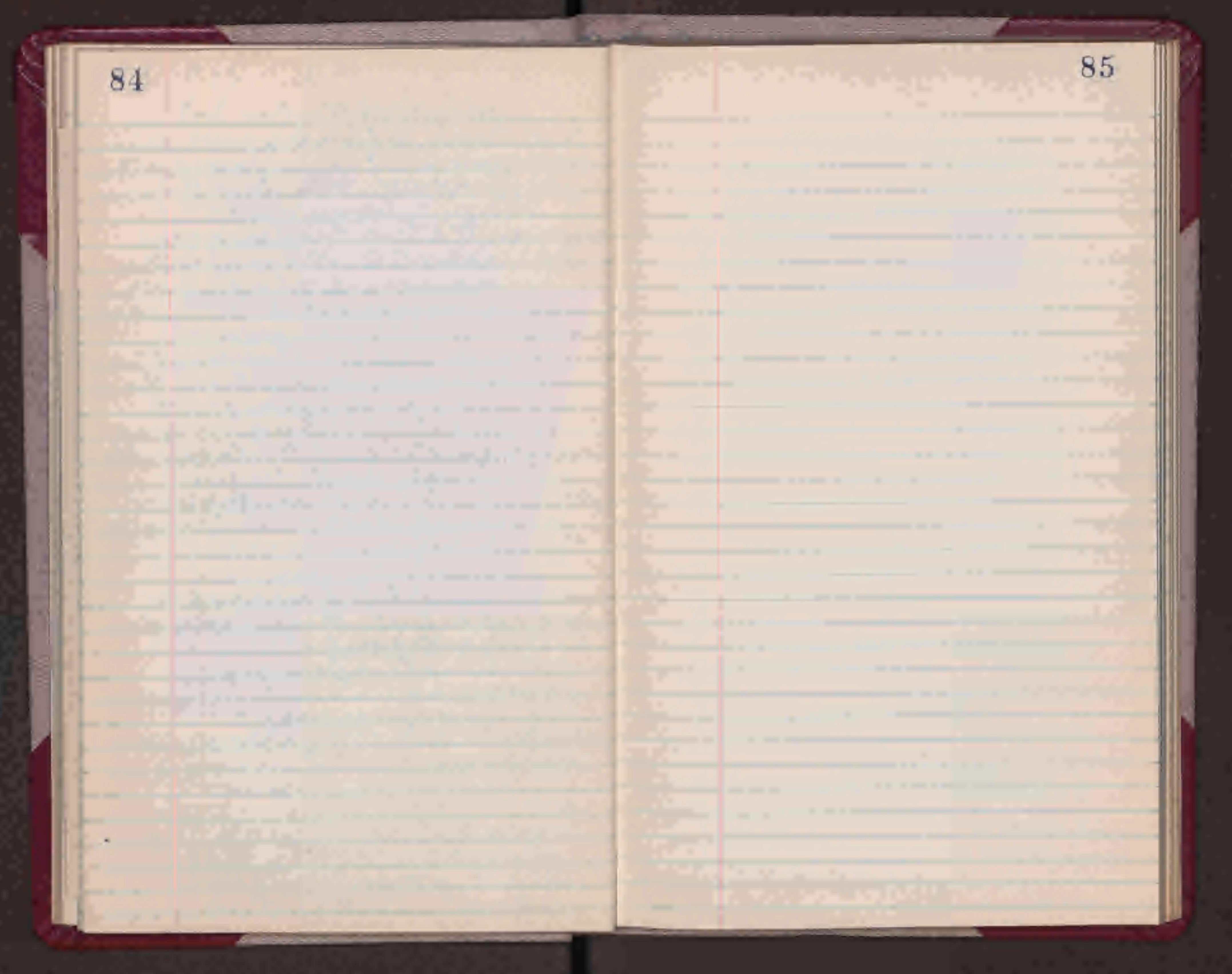




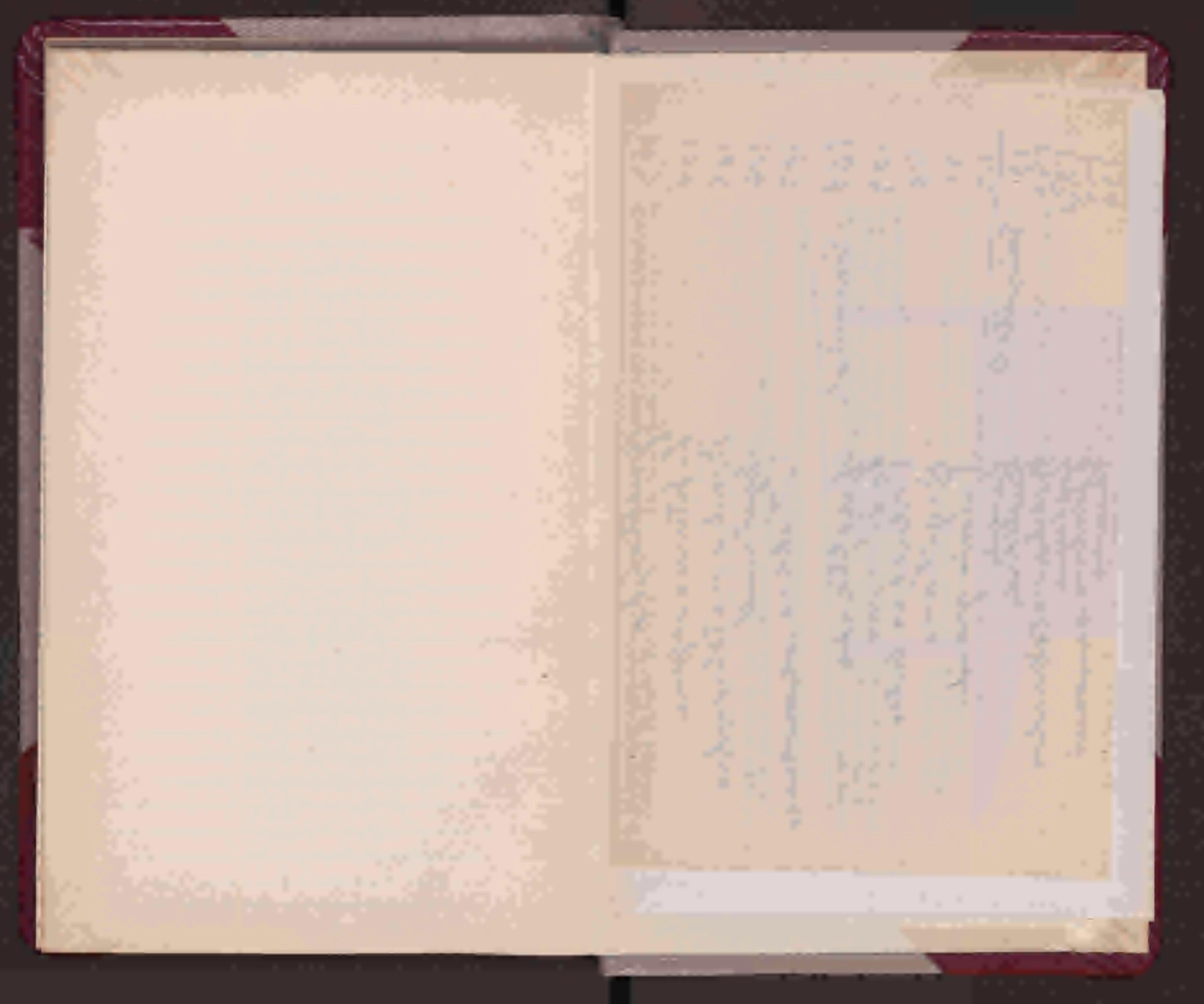


Ponbergo insasta from the Karshall Islands, February 1956.

l. Anta, oollaoted in Guest house, Kajalein Ialet, Kwajalein Atoll. (attraoted by liqueur left in gliasus.)

2. "Brown widew" splder, found it house of Codr. Mhite, whe says it is falriy oomen, but no bitos reported raoutily. Bmajalein Ialet, Ins jalein Atoll.

3. Long homed grasuhoppor nyngh, found in houquat of rlowers on table, tikiep Iolot, Liklop Atoll.

(4. arabe fron Ruzgelap I., Rongelep Atoll).

6. Two grasahpppors nttraoted to lightu, Rongolnp Ialot, Rongelsp Atoll.

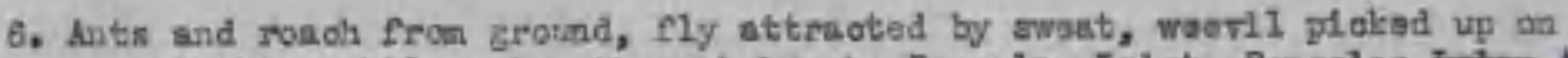
elothing while going through orash, Rougelpp Ir lat, Rongolap isiter Atoll.

(7. hermit ornb from Allinglnas Atol1)

(8. Gaoko, Bniaetok I., Rongerik Ato11).

9, 10, 11. Insecta attracted to If ght in house in viliate, Oterik Islat, Otorlk Atoll (anta on grsund in house, sooningly indifforent to 14 ghat).

12. Insecta agooolated with PAsonia tree trunk (nodquitio larva in wator in hole ir truik, grasshoppor not ospooially asaoolated with anything), siro Iflet, Aflinginse Atoll.

13. Spider, 81fo Islat, Allinglase Atoll.

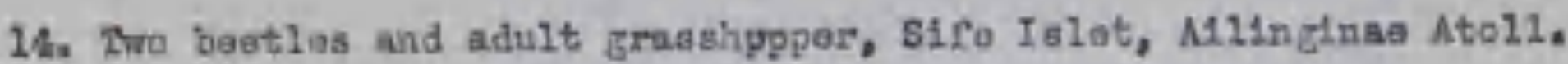

Q5. Hormst arub, top of baash, Gigen Ialet, Rongolag $\Delta$ tall.)

16. Tyloeope whlah atung a men on Krajalain Iolot, Konjalain Atoll.

The numbera for arubs, gocloos, ete., in () marely inaludad to hake the teril os oomplete, but are beine takcen to Washington. Somotinea two numbera are in sarie botile, but I think from notes it will be easy to aocociste numbera with proper inseots. 


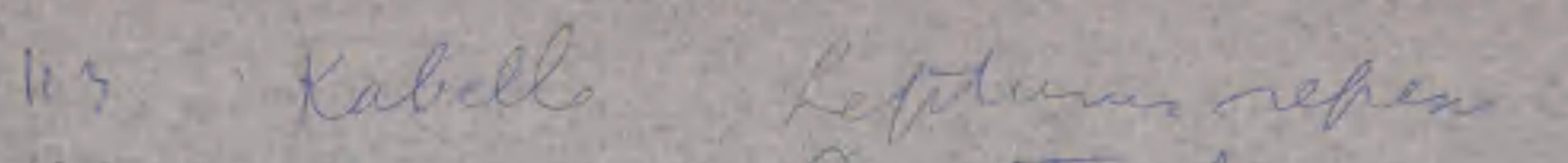

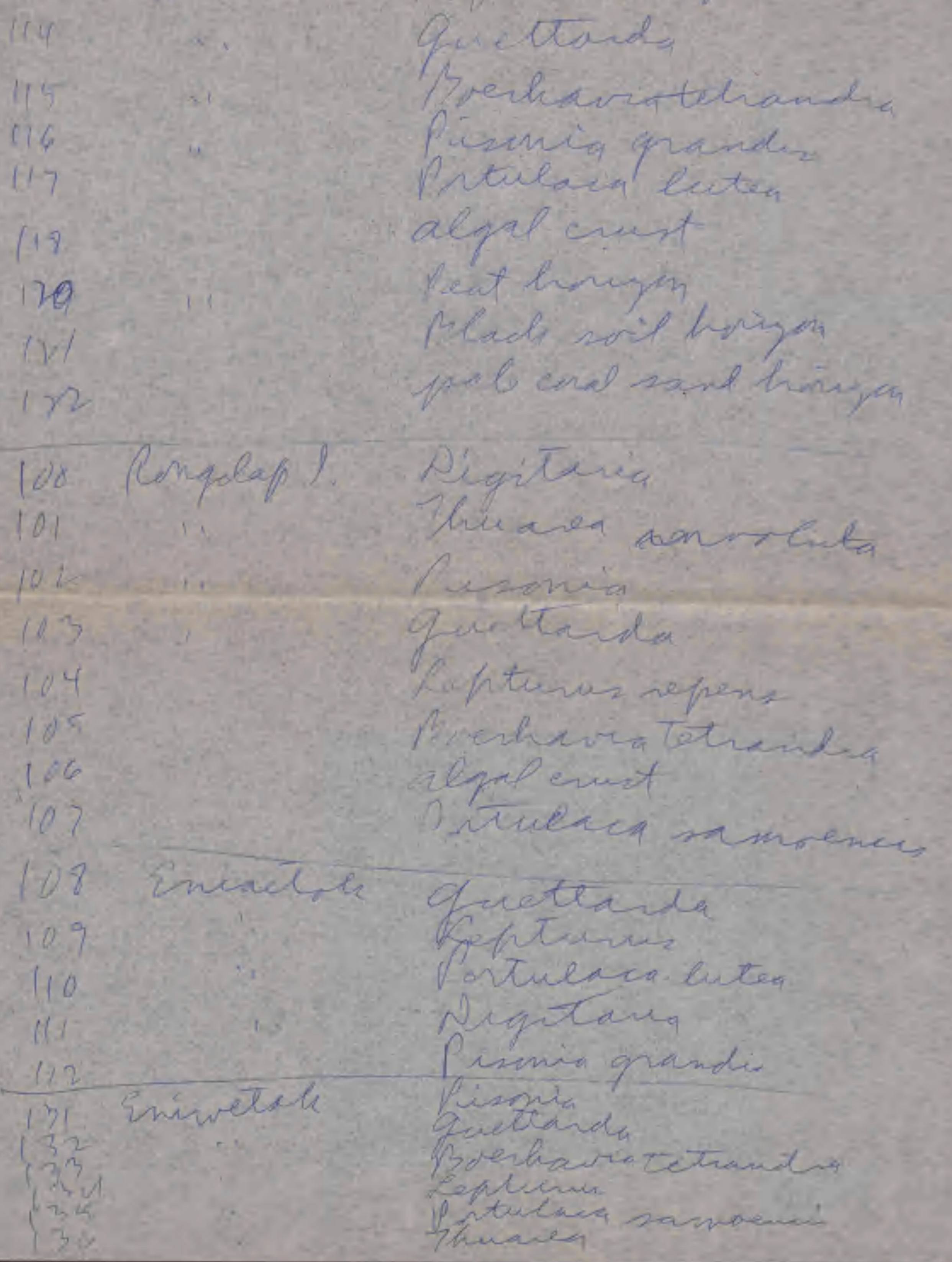




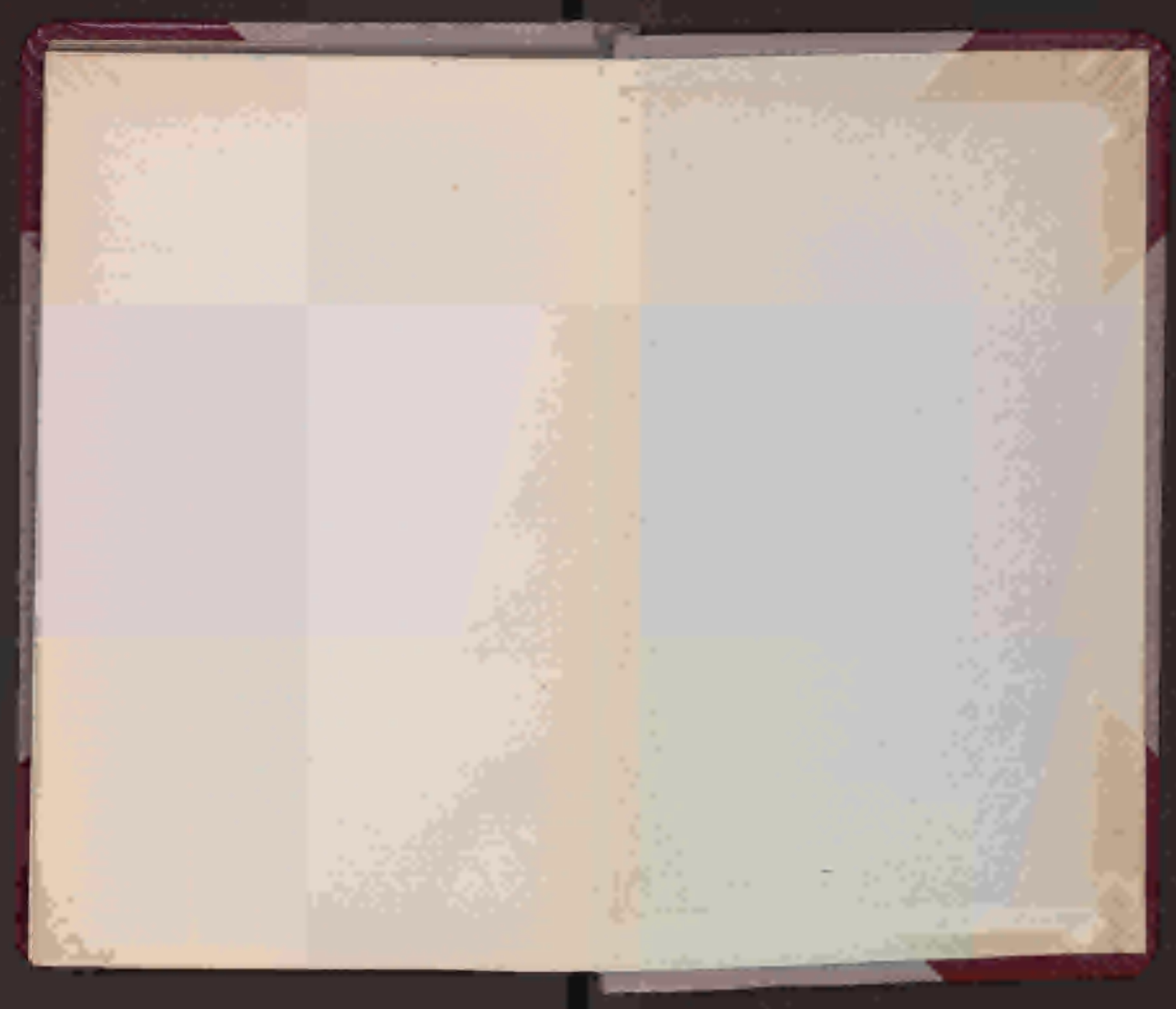




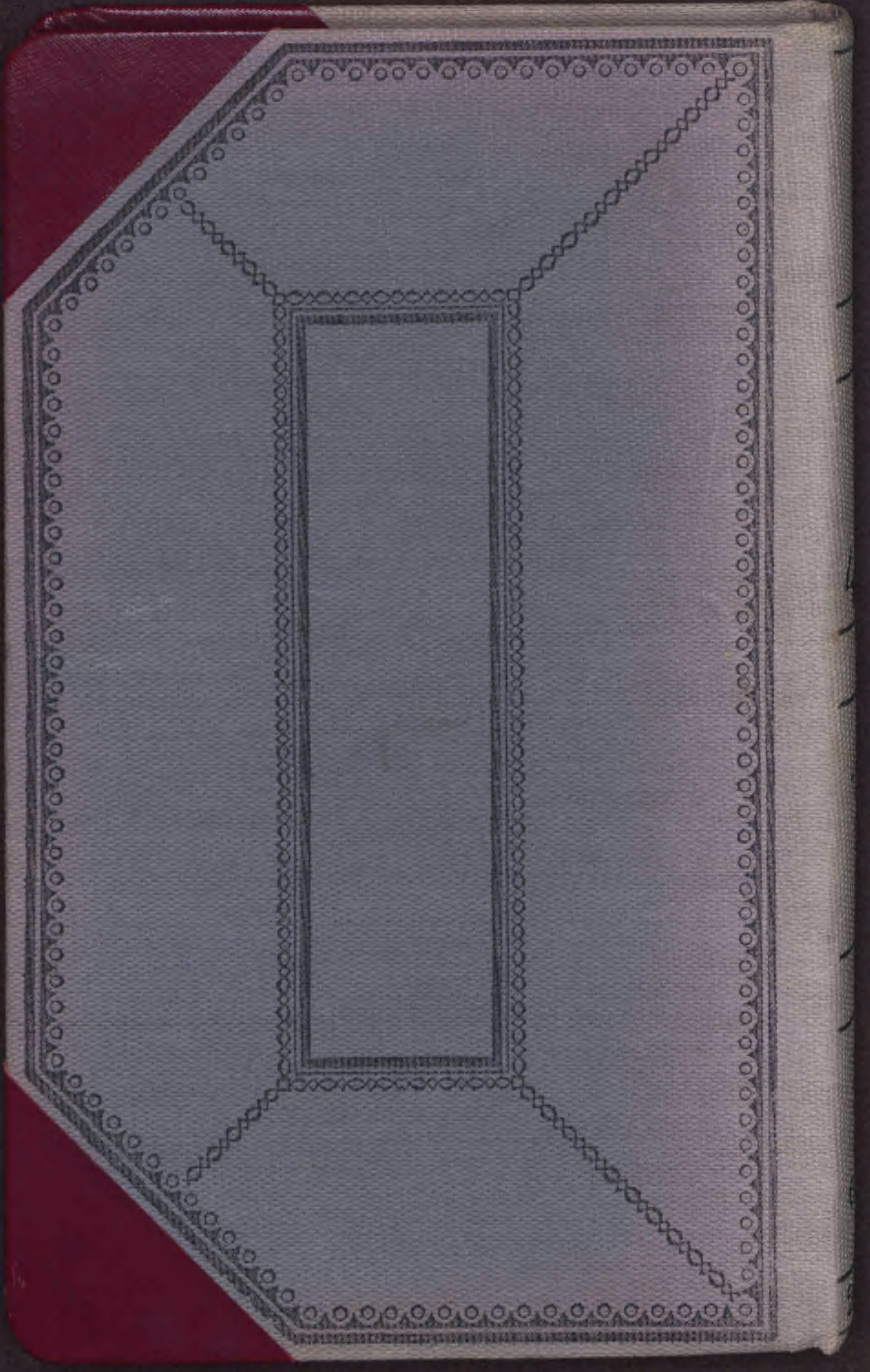

